OPEN ACCESS

Edited by:

Mohammad Anwar Hossain, Bangladesh Agricultural University,

Bangladesh

Reviewed by: Igor Pottosin,

Universidad de Colima, Mexico Ivana Momčilović, Institute for Biological Research

"Siniša Stanković", Serbia

*Correspondence: Alexandra de Sousa alexandradesousa5@gmail.com

tThese authors have contributed equally to this work.

Specialty section:

This article was submitted to Crop Science and Horticulture, a section of the journal Frontiers in Plant Science

Received: 08 March 2016 Accepted: 04 May 2016 Published: 24 May 2016

Citation: de Sousa A, AbdElgawad H, Han A, Teixeira J, Matos $M$ and Fidalgo $F$ (2016) Oxidative Metabolism of Rye (Secale cereale L.) after Short Term Exposure to Aluminum: Uncovering the Glutathione-Ascorbate Redox Network. Front. Plant Sci. 7:685. doi: 10.3389/fpls.2016.00685

\section{Oxidative Metabolism of Rye (Secale cereale L.) after Short Term Exposure to Aluminum: Uncovering the Glutathione-Ascorbate Redox Network}

\author{
Alexandra de Sousa ${ }^{1 *}$, Hamada AbdElgawad ${ }^{2 t}$, Asard Han' ${ }^{2}$, Jorge Teixeira', \\ Manuela Matos ${ }^{3,4}$ and Fernanda Fidalgo ${ }^{1}$
}

1 Biosystems and Integrative Sciences Institute, Departamento de Biologia, Faculdade de Ciências, Universidade do Porto, Porto, Portugal, ${ }^{2}$ Laboratory for Integrated Molecular Plant Physiology Research, Department of Biology, University of Antwerp, Antwerp, Belgium, ${ }^{3}$ Departamento de Genética e Biotecnologia, Universidade de Trás-os-Montes e Alto-Douro, Vila Real, Portugal, ${ }^{4}$ Biosystems and Integrative Sciences Institute, Faculdade de Ciências, Universidade de Lisboa, Lisboa, Portugal

One of the major limitations to plant growth and yield in acidic soils is the prevalence of soluble aluminum ions $\left(\mathrm{Al}^{3+}\right)$ in the soil solution, which can irreversible damage the root apex cells. Nonetheless, many Al-tolerant species overcome Al toxicity and are well-adapted to acidic soils, being able to complete their life cycle under such stressful conditions. At this point, the complex physiological and biochemical processes inherent to Al tolerance remain unclear, especially in what concerns the behavior of antioxidant enzymes and stress indicators at early plant development. Since rye (Secale cereale L.), is considered the most Al-tolerant cereal, in this study we resort to seedlings of two genotypes with different $\mathrm{Al}$ sensitivities in order to evaluate their oxidative metabolism after short term Al exposure. Al-induced toxicity and antioxidant responses were dependent on rye genotype, organ and exposure period. Al affected biomass production and membrane integrity in roots and leaves of the sensitive (RioDeva) genotype. Catalase was the primary enzyme involved in $\mathrm{H}_{2} \mathrm{O}_{2}$ detoxification in the tolerant (Beira) genotype, while in RioDeva this task was mainly performed by GPX and POX. Evaluation of the enzymatic and non-enzymatic components of the ascorbateglutathione cycle, as well the oxalate content, revealed that Beira genotype coped with Al stress by converting DHA into oxalate and tartarate, which posteriorly may bind to Al forming non-toxic chelates. In contrast, RioDeva genotype used a much more ineffective strategy which passed through ascorbate regeneration. So, remarkable differences between MDHAR and DHAR activities appear to be the key for a higher Al tolerance.

Keywords: aluminum, Secale cereale L., oxidative metabolism, ascorbate-glutathione cycle, Al short-term exposure, antioxidant response 


\section{HIGHLIGHT}

At early development stages the underling physiological and biochemical mechanisms to tolerate $\mathrm{Al}$ passes through modulation of ascorbate-glutathione enzymes, essentially MDHAR and DHAR in a genotype-dependent manner.

\section{INTRODUCTION}

Approximately $30-40 \%$ of the world's potentially arable lands are acidic soils, on which $\mathrm{Al}$ is the main factor that limits plant growth and crop production (Kochian et al., 2004). Soils acidification worldwide results from natural and anthropogenic inputs. When soil pH is below 5.0, the phytotoxic ion $\mathrm{Al}^{3+}$ is released into the soil solution resulting in both impaired root growth and early seedling development (Sasaki et al., 2002). Diverse management strategies were used by seed companies and farmers' associations over the last decades to increase soil $\mathrm{pH}$ and reduce Al toxicity. Direct application of lime was the most common method employed. However, disadvantages inherited to this method prompted producers to seek a viable and sustainable solution for this problem (Cassiolato et al., 2000). Observing that some plant species exhibited natural tolerance to $\mathrm{Al}$ toxicity in fields, producers started to ask for the development of new crop varieties with similar characteristics that would allow them to direct future agricultural expansion onto acid soils. Since a great inter- and intraspecific variability has been observed for $\mathrm{Al}$ tolerance, several efforts are in progress in order to identify major genes and associated biochemical and physiological processes underlying $\mathrm{Al}$ resistance in Al-tolerant genotypes. This will provide important resources for further improvement of crop resistance for $\mathrm{Al}$ toxicity trough breeding programs. Thus, it is crucial to thoroughly exploit tolerance mechanisms that operate in early stages of seedling development of Al-tolerant genotypes that lately are able to complete their life cycle under $\mathrm{Al}$ stress conditions. Rye (Secale cereale) is considered the most Altolerant species among Triticeae, but research concerning rye's Al tolerance is extremely limited (Aniol and Gustafson, 1984; Ryan et al., 2011). Uncovering the genetic, molecular and physiological mechanisms involved in rye $\mathrm{Al}$ tolerance will provide vital information that can be used to increase $\mathrm{Al}$ tolerance in other cereals, such as wheat and Triticale.

Several mechanisms involved in the external and/ or internal Al tolerance have been proposed (Huang et al., 2009; Brunner and Sperisen, 2013). However, root exudation of organic acids under $\mathrm{Al}$ stress seems to play a central role in $\mathrm{Al}$ detoxification in several plant species or cultivars, since they can form stable, non-toxic complexes with $\mathrm{Al}^{3+}$ at the rizhosphere. In fact, several genes controlling this trait were identified among cereals, including rye (Ma et al., 2001; Hede et al., 2002; Fontecha et al., 2007;

Abbreviation: Al, aluminum; APX, ascorbate peroxidase; ASC, ascorbate; CAT, catalase; Cys, cysteine; DHAR, dehydroascorbate reductase; EL, electrolyte leakage; Glu, glutamate; Gly, glycine; GPX, guaiacol peroxidase; GR, gluthatione reductase; $\mathrm{GSH}$, glutathione; $\mathrm{H}_{2} \mathrm{O}_{2}$, hydrogen peroxide; LOX, lipoxygenase; MDA, malondialdehyde; MDHAR, monodehydroascorbate reductase; POX, phenol peroxidase; Ser, serine; TAC, total antioxidant capacity.
Yokosho et al., 2010; Ryan et al., 2011). Organic acids, namely oxalic acid have also been implicated in internal $\mathrm{Al}^{3+}$ tolerance once it has entered into root and shoot symplast (Brunner and Sperisen, 2013). Al detoxification is achieved by complexation with oxalate in a 1:1, 1:2, or 1:3 molar ratios, followed by sequestration into vacuoles (Ma, 2000). It's a well-known fact that plant exposure to environmental stresses, including metal toxicity, leads to the formation of peroxides and free radicals that cause damage to proteins, lipids and carbohydrates (Sharma et al., 2012). There has been increasing evidence that $\mathrm{Al}$ affects ROS homeostasis in several plant species. Al triggered ROS production in potato (Tabaldi et al., 2009), rice (Kuo and Kao, 2003), soybean (Cakmak and Horst, 1991), and tobacco (Yamamoto et al., 2002) leading to membrane lipid peroxidation (LP) and consequently, to highly toxic lipid peroxy radicals (Yin et al., 2010). Cell membranes are major targets of Al toxicity in many $\mathrm{Al}$-sensitive species. Al binds to phospholipids and proteins of the plasma membrane altering membrane permeability, fluidity and electrochemical potential. Also, Al interacts with cation channels indirectly suppressing $\mathrm{H}^{+}$-ATPase activity (Zhang and Taylor, 1991; Matsumoto, 2000; Horst et al., 2010). In maize, rather than LP, $\mathrm{Al}$ stress resulted in protein oxidation (Boscolo et al., 2003). Therefore, Al-induced inhibition of root growth may be related to oxidative stress and changes in cell wall biomechanical properties (Yamamoto et al., 2003). To cope with additional ROSgenerating mechanisms, plants developed an efficient enzymatic and non-enzymatic antioxidant defense system which controls the cascades of oxidation and protects plant cells from oxidative damage by scavenging ROS (Sharma et al., 2012). Superoxide dismutase (SOD) is a key antioxidant enzyme considered to be the first line of defense against oxidative stress, since it catalyzes the dismutation of superoxide anion $\left(\mathrm{O}_{2}{ }^{\bullet-}\right)$ into $\mathrm{H}_{2} \mathrm{O}_{2}$ and oxygen $\left(\mathrm{O}_{2}\right) \cdot \mathrm{H}_{2} \mathrm{O}_{2}$ is then reduced to water $\left(\mathrm{H}_{2} \mathrm{O}\right)$ by CAT, APX, GPX, and other POX (Sharma et al., 2012). Ascorbate, carotenoids, flavonoids, gluthatione, phenols, proline, and tocopherols represent the non-enzymatic metabolites of the antioxidant defense system (Sharma et al., 2012). Ascorbate, gluthatione, and proline are powerful antioxidants since they can directly scavenge reactive oxygen species (ROS) like singlet oxygen $\left({ }_{1} \mathrm{O}^{2}\right)$ and hydroxyl radicals $\left(\mathrm{HO}^{\bullet-}\right.$; Foyer and Noctor, 2011; Xu et al., 2012). Ascorbate and gluthatione also serve as electron donors for key enzymes such as APX and GPX and are involved in several physiological mechanisms like cell division and expansion (Noctor et al., 2012). Besides APX, other enzymes involved in the ascorbate-glutathione cycle (ASC-GLU, MDHAR, DHAR, GR) also play an important role in oxidative stress management (Sharma et al., 2012).

However, until now it remains unclear how $\mathrm{Al}$ affects cellular redox homeostasis of rye seedlings after short-term exposure and what molecular mechanisms differ between tolerant and sensitive genotypes. In this work analyses were performed that unravel the physiological and biochemical basis of Al toxicity and tolerance in rye genotypes with emphasis on the antioxidant metabolism. The results allow us to understand how rye genotypes are capable of modulating their metabolic and physiological responses in order to cope with $\mathrm{Al}$ stress in early development stages. We also observed that metabolic modifications are organ specific within 
each genotype, and how it reflected on different morphological characteristics.

\section{MATERIALS AND METHODS}

\section{Rye Lines and Experimental Setup}

Seeds of two rye genotypes, an Al-tolerant cultivar, Beira (Portuguese Regional Cultivar), and an Al-sensitive, RioDeva (Spanish inbreed line), were kindly provided by University of Trás-os-Montes e Alto Douro (UTAD/Vila Real/Portugal). Surface-sterilized seeds [sodium hypochlorite $5 \%(\mathrm{w} / \mathrm{v}), 10 \mathrm{~min}$ ] were rinsed in sterile deionized water and germinated in the dark at $25^{\circ} \mathrm{C}$ in Petri dishes. Seedlings were hydroponically cultured in a modified Hoagland's solution containing: $\mathrm{CaCl}_{2}$ $22.20 \mathrm{~g} \mathrm{~L}^{-1}, \mathrm{KNO}_{3} 32.86 \mathrm{~g} \mathrm{~L}^{-1}, \mathrm{MgCl}_{2} .6 \mathrm{H}_{2} \mathrm{O} 25.41 \mathrm{~g} \mathrm{~L}^{-1}$, $\left(\mathrm{NH}_{4}\right)_{2} \mathrm{SO}_{4} 0.66 \mathrm{~g} \mathrm{~L}^{-1}, \mathrm{NH}_{4} \mathrm{NO}_{3} 1.60 \mathrm{~g} \mathrm{~L}^{-1}$ and maintained at $25^{\circ} \mathrm{C}$ under a $16 / 8 \mathrm{~h}$ photoperiod with a photosynthetically active radiation (PAR) of $60 \mu \mathrm{mol} \mathrm{m} \mathrm{m}^{-2} \mathrm{~s}^{-1}$. After $48 \mathrm{~h}$ roots and leaves were collected $\left(0 \mathrm{~h} ; 0 \mathrm{mg} \mathrm{L}^{-1}\right)$ and the remaining seedlings were transferred to a new nutritive solution with the same mineral composition described above, supplemented with $5 \mathrm{mg} \mathrm{L}^{-1}$ of $\mathrm{Al}^{3+}$ in the form of $\mathrm{AlCl}_{3} \cdot 6 \mathrm{H}_{2} \mathrm{O}$. Samples of roots and leaves were collected 24 and $48 \mathrm{~h}$ after exposure to the $\mathrm{Al}$ treatment. Again, the remaining seedlings were transferred to a new nutritive solution without $\mathrm{Al}$ (recovery treatment) and samples were collected $48 \mathrm{~h}$ later $\left(96 \mathrm{~h} ; 0 \mathrm{mg} \mathrm{L}^{-1}\right)$. Biomass production of rye seedlings was determined as fresh weight for each experimental condition. Root length was determined after the recovery period. The nutrient solution was continuously aerated and the $\mathrm{pH}$ was maintained at 4.0 throughout the assays. All samples were immediately frozen in liquid nitrogen and grinded to a fine powder and finally stored at $-80^{\circ} \mathrm{C}$ for biochemical analyzes. Negative controls of selected parameters were performed in a second group of plants grown on the same conditions stated before, but without $\mathrm{Al}$ in order to differentiate between $\mathrm{Al}$ toxicity effects and development effects.

\section{Al Tolerance Screening Tests}

The Al tolerance screening test was performed by a modifiedpulse method (Aniol and Gustafson, 1984). After the recovery treatment, seedlings were washed 3 min with running distilled water and stained with $0.1 \%(\mathrm{w} / \mathrm{v})$ Eriochrome cyanine $R$ for $10 \mathrm{~min}$. This dye forms a stable bluish complex with Al. Excess dye was washed from rye roots and seedlings were transferred to $\mathrm{Al}$ - free nutrient solution for $48 \mathrm{~h}$. Al tolerance was measured as root regrowth of seedlings.

\section{Oxidative Stress Parameters}

Lipid peroxidation was determined according to Murshed et al. (2008). Briefly, $100 \mathrm{mg}$ of frozen tissue were homogenized (MagNALyser, Roche, Vilvoorde, Belgium; $1 \mathrm{~min}, 7000 \mathrm{rpm}$ ) in $1 \mathrm{~mL}$ of $80 \%(\mathrm{v} / \mathrm{v})$ ethanol. After centrifugation $(12,000 \mathrm{~g}$, $15 \mathrm{~min}) 0.5 \mathrm{~mL}$ of the supernatant was added to $1 \mathrm{~mL}$ of $0.5 \%$ $(\mathrm{w} / \mathrm{v})$ TBA in $20 \%(\mathrm{w} / \mathrm{v})$ TCA. The samples were incubated at $95^{\circ} \mathrm{C}$ for $30 \mathrm{~min}$, and the reaction stopped by placing the reaction tubes in an ice bath $(10 \mathrm{~min})$ followed by a centrifugation for $2 \mathrm{~min}$ at $10,000 \mathrm{~g}$. Absorbance was measured at 450, 532, and $600 \mathrm{~nm}$ in a microplate reader. TBARS equivalents were calculated by the following formula: [6.45 x $\left(\mathrm{Abs}_{532}-\mathrm{Abs}_{600}\right)$ $\left.0.56 \times \mathrm{Abs}_{450}\right]$ and expressed as nmol MDA g $\mathrm{g}^{-1} \mathrm{FW}$. EL was measured according to the method of Lutts et al. (1996). Seedlings were washed several times with deionized water and, after drying, tissue samples were immersed in $10 \mathrm{~mL}$ of deionized water and incubated at $25^{\circ} \mathrm{C}$ in a rotary shaker $(100 \mathrm{rpm})$. Electrical conductivity of the bathing solution (T1) was recorded after $24 \mathrm{~h}$. Samples were immediately autoclaved at $120^{\circ} \mathrm{C}$ for $20 \mathrm{~min}$ and a last conductivity reading (T2) was obtained when the solutions reached $25^{\circ} \mathrm{C}$. EL was expressed following the formula: $\left[\mathrm{I}(\%)=\left[1-\left(1-\mathrm{T}_{1}-\mathrm{T}_{2}\right) /\left(1-\left(\mathrm{C}_{1}-\mathrm{C}_{2}\right)\right)\right] \times 100\right]$, where $\mathrm{C}$ corresponds to the control situations and $\mathrm{T}$ to the treated samples. An Amplex Red Hydrogen Peroxide/Peroxidase Assay Kit (Molecular Probes, Eugene, OR, USA) was used to measure $\mathrm{H}_{2} \mathrm{O}_{2}$ production.

\section{Scavenging Activity of Hydrogen Peroxide $\left(\mathrm{H}_{2} \mathrm{O}_{2}\right)$}

Scavenging activity of $\mathrm{H}_{2} \mathrm{O}_{2}$ was determined according to Ngonda (2013). Samples were washed with distilled water and dried at $55^{\circ} \mathrm{C}$ during $48 \mathrm{~h}$. After, leaf and root tissues (500 mg) were grinded into a fine powder and mixed with $2 \mathrm{~mL}$ of $95 \%(\mathrm{v} / \mathrm{v}) \mathrm{MeOH}$. The residue was re-extracted under the same conditions until the supernatant became achromatic. Excess $\mathrm{MeOH}$ was removed from extracts in a rotary evaporator at $40^{\circ} \mathrm{C}$. Dry extracts were stored at $-20^{\circ} \mathrm{C}$ until further analysis. Briefly, a solution of $\mathrm{H}_{2} \mathrm{O}_{2}$ was prepared in phosphate buffer (pH 7.4). Plant extracts $(100 \mu \mathrm{g} / \mathrm{mL})$ were added to $0.6 \mathrm{~mL}$ of $\mathrm{H}_{2} \mathrm{O}_{2}$ solution and the final volume of $3 \mathrm{~mL}$ was made by adding the phosphate buffer ( $\mathrm{pH}$ 7.4). The absorbance of the reaction mixture was measured at $230 \mathrm{~nm}$ against a blank solution. The percentage of $\mathrm{H}_{2} \mathrm{O}_{2}$ scavenging by the rye extracts were calculated as:

$$
\% \text { Scavenged }\left[\mathrm{H}_{2} \mathrm{O}_{2}\right]=\left[\left(\mathrm{A}_{0}-\mathrm{A}_{1}\right) / \mathrm{A}_{0}\right] \times 100
$$

Where, $\mathrm{A}_{0}$ - Absorbance of control;

$A_{1}$ - Absorbance of extracts.

\section{Non-enzymatic Antioxidants}

Ascorbate and glutathione levels were determined by HPLC analyses (Potters et al., 2004). Samples were extracted in $1 \mathrm{~mL}$ of ice-cold 6\% (w/v) meta-phosphoric acid and after centrifugation $\left(16,000 \mathrm{~g}, 4^{\circ} \mathrm{C}, 10 \mathrm{~min}\right)$ antioxidants were separated on a reverse-phase column $(100 \mathrm{~mm} \times 4.6 \mathrm{~mm}$ Polaris C18-A, $3 \mu \mathrm{m}$ particle size; $40^{\circ} \mathrm{C}$, Varian, CA, USA) with an isocratic flow rate of $1 \mathrm{~mL} \mathrm{~min}{ }^{-1}$ of the elution buffer: $2 \mathrm{mM} \mathrm{KCl}$, $\mathrm{pH} 2.5$ adjusted with $O$-phosphoric acid. Antioxidants were quantified using an electrochemical detector and the purity and identity of the peaks were confirmed using an in-line DAD (SPD-M10AVP, Shimadzu). Total antioxidant concentration was determined after reduction of samples with $0.04 \mathrm{M} \mathrm{DTT}$, for $10 \mathrm{~min}$ in obscurity and the redox status was calculated as the ratio of the reduced form to the total antioxidant concentration. Tocopherols $(\alpha, \beta, \gamma$, $\delta$ ) were determined by HPLC analysis according to AbdElgawad et al. (2015). Tocopherols were extracted with hexane using the 
MagNALyser (Roche, Vilvoorde, Belgium; $1 \mathrm{~min}, 7000 \mathrm{rpm}$ ). The dried extract (CentriVap concentrator, Labconco, KS, USA) was resuspended in hexane, and tocopherols were separated and quantified by HPLC (Shimadzu, 's-Hertogenbosch, The Netherlands; normal phase conditions, Particil Pac $5 \mu \mathrm{m}$ column material, length $250 \mathrm{~mm}$, i.d. $4.6 \mathrm{~mm}$ ). Dimethyl tocol (DMT) was used as internal standard (5 ppm). Data were analyzed with Shimadzu Class VP 6.14 software. The TAC of plant extracts was determined by a modified ferric ion reducing antioxidant power (FRAP) assay (Benzie and Szeto, 1999). Antioxidants were extracted by grinding $100 \mathrm{mg}$ of frozen plant tissue in $1 \mathrm{~mL}$ of $80 \%(\mathrm{v} / \mathrm{v})$ ethanol. After centrifugation $\left(3,000 \mathrm{~g}, 4^{\circ} \mathrm{C}, 15 \mathrm{~min}\right)$ the FRAP reagent ( $0.3 \mathrm{M}$ acetate buffer, $\mathrm{pH} 3.6,0.01 \mathrm{mM}$ TPTZ in $0.04 \mathrm{mM} \mathrm{HCl}, 0.02 \mathrm{M} \mathrm{FeCl}_{3} \cdot 6 \mathrm{H}_{2} \mathrm{O}$ ) was mixed with the extracts and measured at $600 \mathrm{~nm}$, using Trolox as a standard.

\section{Enzyme Assays}

Lipoxygenase (EC 1.13.11.12) was extracted in $50 \mathrm{mM}$ sodium phosphate buffer ( $\mathrm{pH} 7.0$ ) containing $1 \mathrm{mM}$ EDTA, $0.1 \mathrm{mM}$ PMSF, 2\% (w/v) PVP, 1\% glycerol and 0.1\% Tween 20. After centrifugation $\left(15,000 \mathrm{~g}, 4^{\circ} \mathrm{C}, 20 \mathrm{~min}\right), 2.9 \mathrm{~mL}$ of the assay solution ( $1 \mathrm{mM}$ linoleic acid in $0.1 \mathrm{M}$ sodium acetate buffer) was added to $0.1 \mathrm{~mL}$ of the plant extract and absorbance was measured at $240 \mathrm{~nm}$. LOX activity was calculated using the extinction coefficient of conjugated dienes $\left(\varepsilon_{340}=25 \mathrm{mM}^{-1} \mathrm{~cm}^{-1}\right.$; Ramakrishna and Rao, 2012).

Catalase (EC 1.11.1.6) and GPX (EC 1.11.1.7) were extracted in a $50 \mathrm{mM}$ potassium phosphate $(\mathrm{pH} 7.0)$ containing $0.4 \mathrm{mM}$ EDTA, $0.2 \mathrm{mM}$ PMSF, 2\% (w/v) insoluble PVPP and $1 \mathrm{mM}$ ascorbic acid. Other antioxidant enzymes such, APX (EC 1.11.1.11), MDHAR (EC 1.6.5.4), DHAR (EC 1.8.5.1), GR (EC 1.8.1.7), and POX (EC 1.11.1.7) were extracted in $50 \mathrm{mM}$ MES/KOH buffer ( $\mathrm{pH} 6.0$ ), containing $2 \mathrm{mM} \mathrm{CaCl}_{2}, 40 \mathrm{mM}$ $\mathrm{KCl}$, and $1 \mathrm{mM}$ ascorbic acid. CAT activity was determined spectrophotometrically at $240 \mathrm{~nm}$ by monitoring the rate of $\mathrm{H}_{2} \mathrm{O}_{2}$ decomposition at $\mathrm{pH} 7.0$ (Aebi, 1984). APX, MDHAR, DHAR, and GR activities were determined according to Murshed et al. (2008). GPX activity was calculated by measuring the decrease in NADPH absorbance at $340 \mathrm{~nm}$ (Drotar et al., 1985). Peroxidase activity was determined by the oxidation of pyrogallol $\left(\varepsilon_{340}=2.47 \mathrm{mM}^{-1} \mathrm{~cm}^{-1} ;\right.$ Kumar and Khan, 1982). The soluble protein content was obtained (Lowry et al., 1951) and activity measurements were scaled down for semi-high throughput measurement using a micro-plate reader (Synergy Mx, Biotech Instruments, Inc., Winooski, VT, USA).

\section{Amino Acids Measurements}

Ethanolic extracts of rye seedlings were used to assay free amino acids (FAAs) levels using a Waters Acquity UPLCtqd system (Milford, MA, USA) equipped with a $\mathrm{BEH}$ amide $2.1 \times 50$ column according to Sinha et al. (2013) with the minor modification previously described by AbdElgawad et al. (2015).

\section{Oxalate Quantification}

Plant samples (100 mg FW) were homogenized in phosphoric acid ( $0.1 \%$; containing $0.003 \%$ butylated hydroxyanisole) using a MagNALyser. The extract was centrifuged at 14, $000 \mathrm{~g}$ for $30 \mathrm{~min}$ at $4^{\circ} \mathrm{C}$. The supernatants were passed through Millipore micro filters $(0.2 \mu \mathrm{M}$ pore size). Oxalate was detected by HPLC using a SUPELCOGEL C-610H column $(300 \mathrm{~mm} \times 7.8 \mathrm{~mm}$, Supelco, Sigma, St. Louis, MO, USA) coupled to UV detection system set at 210 nm (LaChrom L-7455 diode array, LaChrom, Tokyo, Japan). The mobile phase was a $0.1 \%$ phosphoric acid at a flow rate of $0.45 \mathrm{~mL} \mathrm{~min}^{-1}$. Organic acids were quantified using a calibration curve obtained with the corresponding standards.

\section{Statistical Analysis}

Results were expressed as mean \pm SD (standard deviation) and analyzed by two-way ANOVA using IBM SPSS Statistica 23 software package (SPSS ${ }^{\circledR}$ Inc., Chicago, IL, USA) for windows, with organs and concentrations used as fixed variables. Data were tested for normal distribution and homogeneity and normalized when necessary. The significance level of 0.05 was used for rejection of the null hypothesis. In cases of significant interactions between factors, one-way ANOVA analysis was performed for each factor, and Tukey's multiple range tests were used for determining significant differences among means. All experiments were carried out in quadruplicate $(n=4)$, except for biomass determination, where $n=30$, and root length, where $n=100$.

\section{RESULTS}

\section{Plant Growth Response}

Significant differences in growth have been observed between rye genotypes, with higher biomass in Beira seedlings for both leaves and roots (Figures 1A,B). In RioDeva leaves no significant increase in fresh weight was observed between the beginning ( $24 \mathrm{~h} ; 5 \mathrm{mg} \mathrm{L}^{-1}$ ) and end of the Al treatment ( $48 \mathrm{~h} ; 5 \mathrm{mg} \mathrm{L}^{-1}$ ). During recovery period, leaf biomass increased by 44 and $80 \%$ in Beira and RioDeva seedlings, respectively, compared to seedlings exposed $48 \mathrm{~h}$ to $\mathrm{Al}$ treatment (Figure 1A). Despite RioDeva roots presented the same response as leaves, Al did not significantly affected root development in Beira seedlings (Figure 1B). Biomass of RioDeva roots also increased by $25 \%$ during recovery period $\left(96 \mathrm{~h}, 0 \mathrm{mg} \mathrm{L}^{-1}\right.$ ). Measurements carried after the recovery period demonstrated that RioDeva root length was $45 \%$ inferior to the tolerant genotype (Figure 1C). Leaves, as well as roots, of Beira and RioDeva seedlings grown in the absence of $\mathrm{Al}$ exhibited similar biomass at different time points. This indicates that $\mathrm{Al}$, rather than developmental processes, is responsible for the observed decline in biomass, especially in the sensitive RioDeva genotype (Supplementary Figure S1).

\section{Al Screening Tolerance}

Al tolerance varies among rye genotypes and is often based on root regrowth after short periods of $\mathrm{Al}$ exposure. After the recovery treatment all the seedlings of Beira presented root regrowth, while roots of the Al-sensitive seedlings did not presented any regrowth (Figures 2A,C,D). It was also noticed that $56 \%$ of root regrowth in Beira seedlings was equal or superior to $16 \mathrm{~mm}$ (Figure 2B). Optical microscopic observations of roots (data not shown) demonstrated that after the recovery period, 

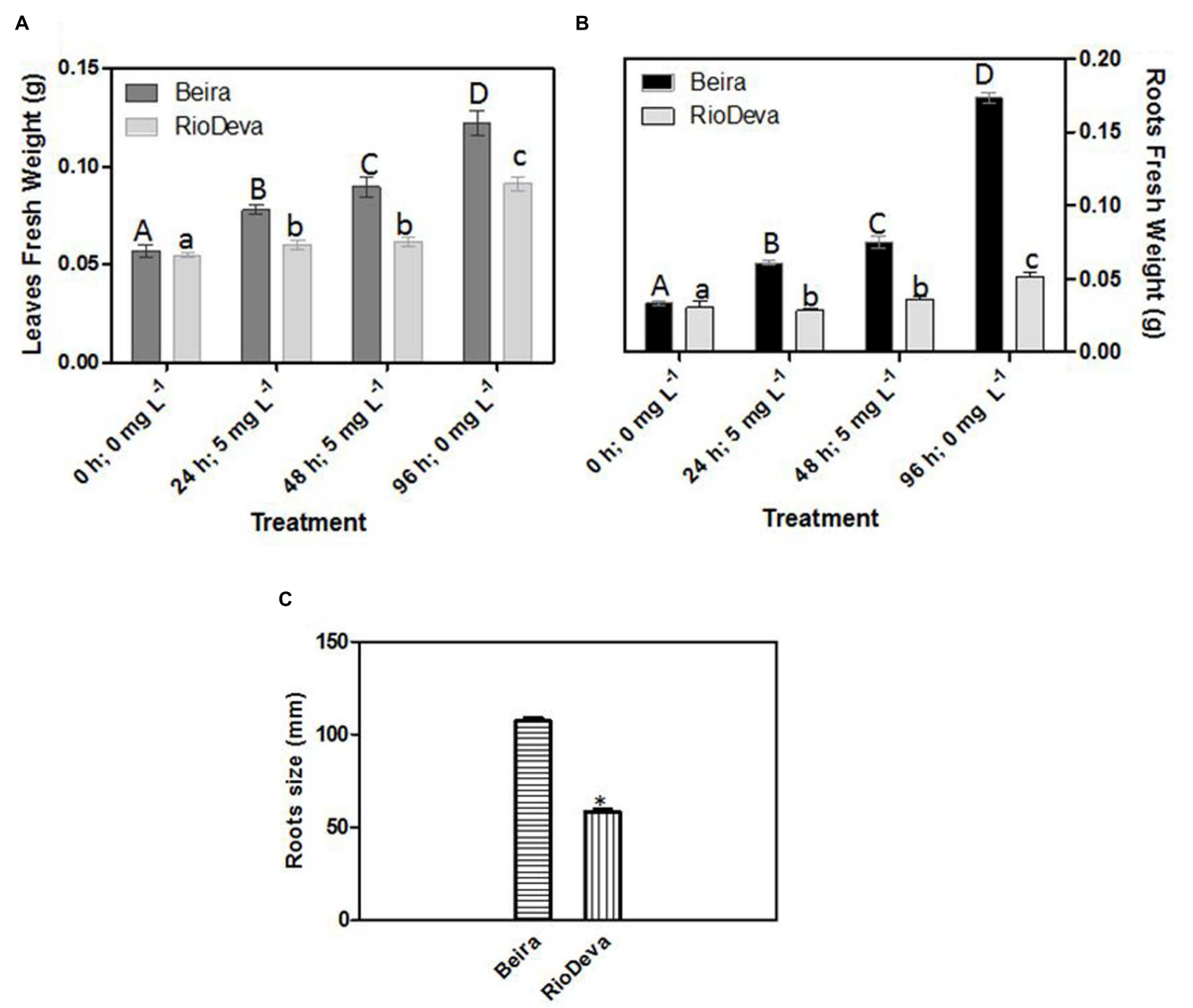

Rye cultivars

FIGURE 1 | Biometric analysis: fresh weight in leaves (A) and roots (B) of rye Al-tolerant (Beira) and Al-sensitive (RioDeva) genotypes and measurement of root length $\mathbf{( C )}$ after the recovery period (96 $\mathbf{~}$; $\mathbf{0} \mathbf{~ p p m ) . ~ D i f f e r e n t ~ u p p e r c a s e ~ l e t t e r s ~ r e p r e s e n t ~ s i g n i f i c a n t ~ d i f f e r e n c e s ~ b e t w e e n ~ t i m e s ~ i n ~ B e i r a , ~}$ while lowercase letters represent significant differences between times in RioDeva. Values represent mean \pm SD $(n=30)$. Asterisk represents significant differences between genotypes in root length. Values represent mean $\pm \operatorname{SD}(n=100)$.

Beira seedlings accumulated $\mathrm{Al}$ in large amounts in lateral root primordia (LRP) and in the hair roots (HRs). Al accumulation in RioDeva genotype was observed in all cells of root tips and in the vascular tissues. HR and LRP were less abundant in this cultivar and did not present any signals of $\mathrm{Al}$ accumulation.

\section{Oxidative Stress - MDA Content, Electrolyte Leakage, LOX Activity, and $\mathrm{H}_{2} \mathrm{O}_{2}$ Content}

Oxidative membrane damage was more severe in the sensitive genotype under all experimental conditions. The highest values of MDA were found in leaves of the sensitive RioDeva genotype $48 \mathrm{~h}$ after exposure to $\mathrm{Al}$, increasing $78 \%$ when compared to control seedlings. In the recovery period ( $\left.96 \mathrm{~h} ; 0 \mathrm{mg} \mathrm{L}^{-1}\right)$,
MDA content decreased significantly almost reaching the values quantified in the control situation ( $0 \mathrm{~h}, 0 \mathrm{mg} \mathrm{L}{ }^{-1}$; Figure 3A). Roots of RioDeva seedlings presented a similar behavior to those found in leaves, while no fluctuations in MDA levels were found in roots of Beira seedlings (Figure 3D). Changes in EL and LOX activity followed the same tendencies as MDA accumulation, except in roots of both genotypes at the end of Al treatment $\left(48 \mathrm{~h} ; 5 \mathrm{mg} \mathrm{L}^{-1}\right)$ and in the recovery period (96 h; $0 \mathrm{mg} \mathrm{L}^{-1}$; Figures 3B,C,E-G). $\mathrm{H}_{2} \mathrm{O}_{2}$ levels were higher in leaves of both genotypes when compared to roots; however, both organs of the Al-sensitive genotype, presented the highest concentration of this ROS (Figures 3D,H). Late exposure of rye seedlings to $\mathrm{Al}\left(48 \mathrm{~h}, 5 \mathrm{mg} \mathrm{L}{ }^{-1}\right)$ resulted in a 1.5 - and 2.2fold increase in $\mathrm{H}_{2} \mathrm{O}_{2}$ content in leaves of Beira and RioDeva genotypes, respectively. A significant decrease was also noticed 


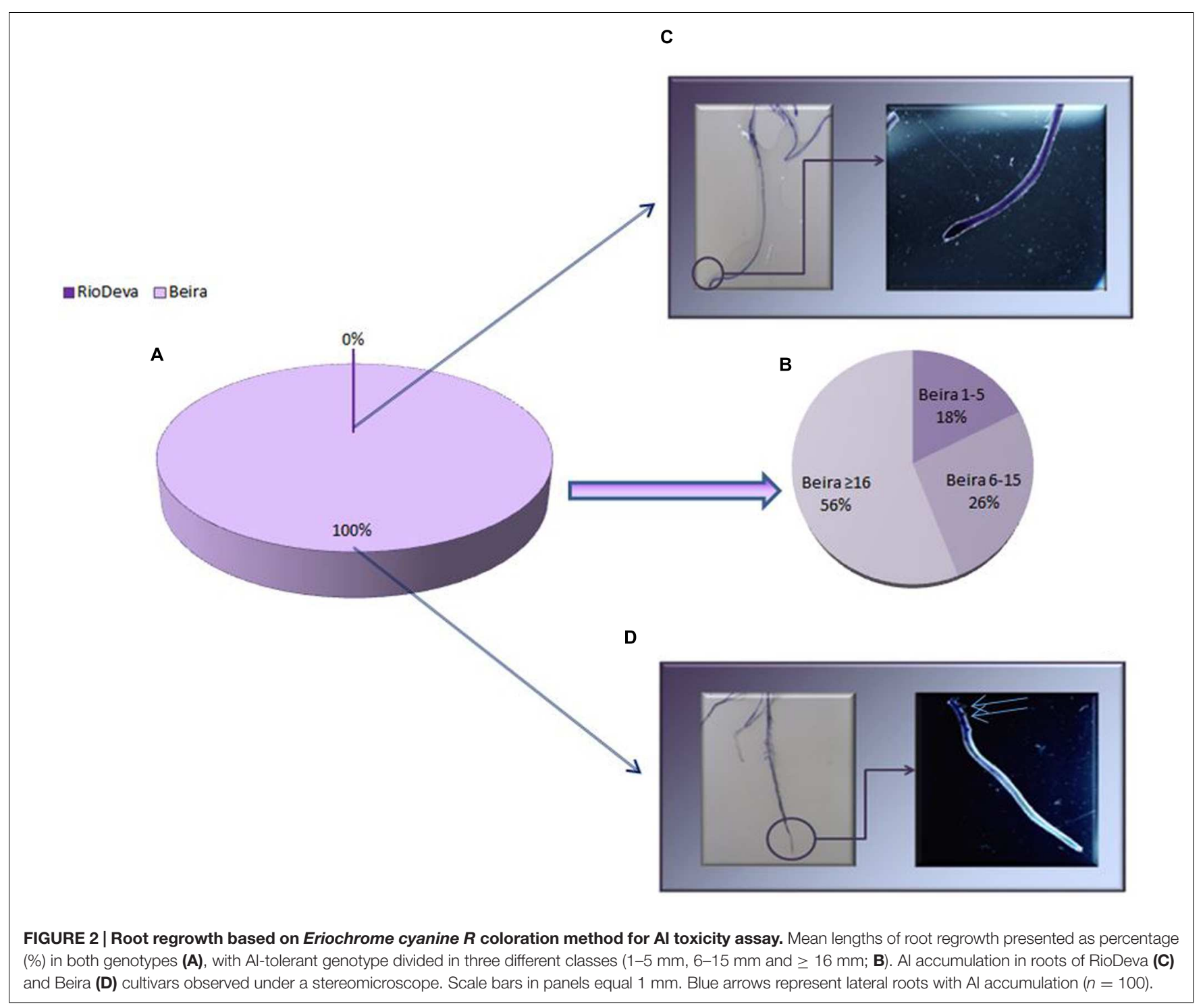

in the recovery period (Figure 3D). Changes in $\mathrm{H}_{2} \mathrm{O}_{2}$ levels in roots followed the same tendency as leaves for both genotypes (Figure 3H). Seedlings grown in the absence of Al showed that differences in the oxidative parameters were majorly due to the effect of $\mathrm{Al}$ treatment, in both organs of the rye Al-tolerant and Al-sensitive genotypes (Supplementary Figure S2).

\section{ROS Homeostasis $-\mathrm{H}_{2} \mathrm{O}_{2}$ Scavenging Activity}

Compared to the sensitive genotype, $\mathrm{H}_{2} \mathrm{O}_{2}$ scavenging activity in leaves was higher in Beira genotype; decreasing $12 \%$ after early exposure to $\mathrm{Al}$. In RioDeva leaves $\mathrm{H}_{2} \mathrm{O}_{2}$ scavenging activity decreased 11 and $33 \%$ after 24 and $48 \mathrm{~h}$ after $\mathrm{Al}$ treatment (Figure 4A). In roots, $\mathrm{H}_{2} \mathrm{O}_{2}$ scavenging activity was higher in Beira seedlings, decreasing $31 \%$ after $48 \mathrm{~h}$ of $\mathrm{Al}$ exposure. For the same period, $\mathrm{H}_{2} \mathrm{O}_{2}$ scavenging activity in RioDeva roots decreased 42\% (Figure 4B).

\section{Cellular Redox Homeostasis - Enzymatic and Non-enzymatic Response}

Hydrogen peroxide levels are controlled by the activity of several enzymes (Figures 5A-H). Enzymatic activity analysis showed that APX was compromised in leaves and roots of both genotypes in response to Al stress $\left(48 \mathrm{~h} ; 5 \mathrm{mg} \mathrm{L}^{-1}\right.$; Figures 5A,E). Catalytic activity of APX seems to be differentially regulated in both genotypes through an organ-specific manner, while CAT, GPX, and POX activities seem to be regulated in a genotype-specific manner. For both organs, CAT activity was higher in Beira genotype, while GPX and POX activities were strongly induced in RioDeva seedlings (Figures $5 \mathbf{B}-\mathbf{H}$ ). Changes in the ASC-GLU metabolism were both regulated by a genotype- and organ-specific manner (Figures 6A-N). ASC levels were higher in leaves of Beira seedlings, increasing $23 \%$ at the beginning of the stress $\left(24 \mathrm{~h} ; 5 \mathrm{mg} \mathrm{L}^{-1}\right)$. No significant variations were found in ASC content of RioDeva leaves (Figure 6A). In roots, ASC levels were remarkably 


\section{Leaves}

A

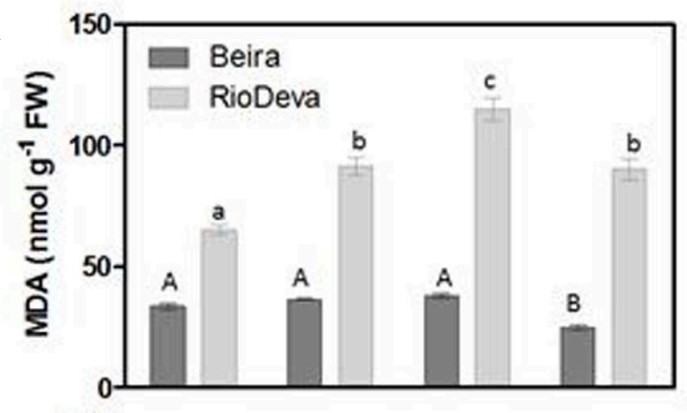

B

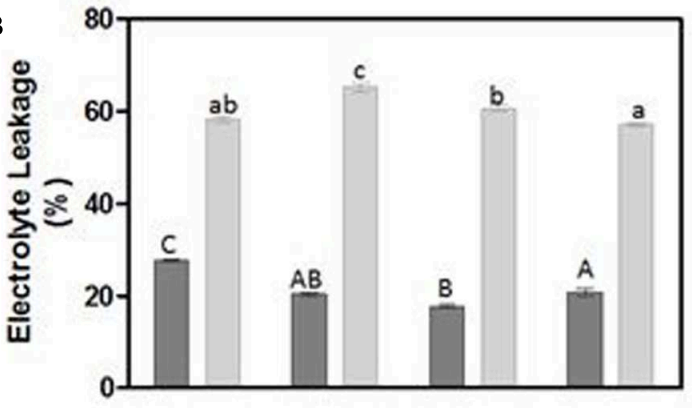

C
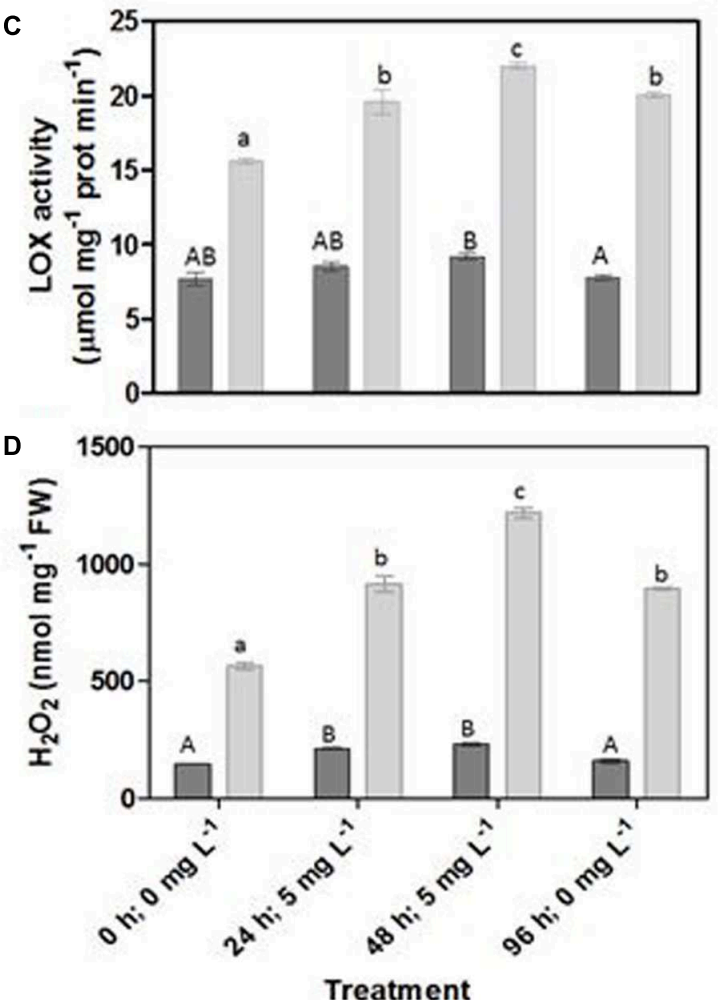

\section{Roots}

E

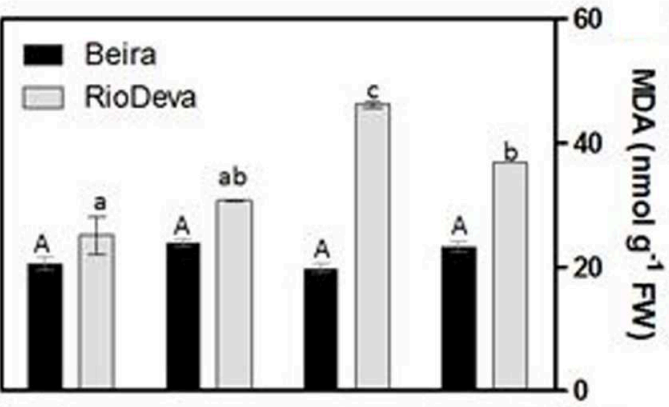

F

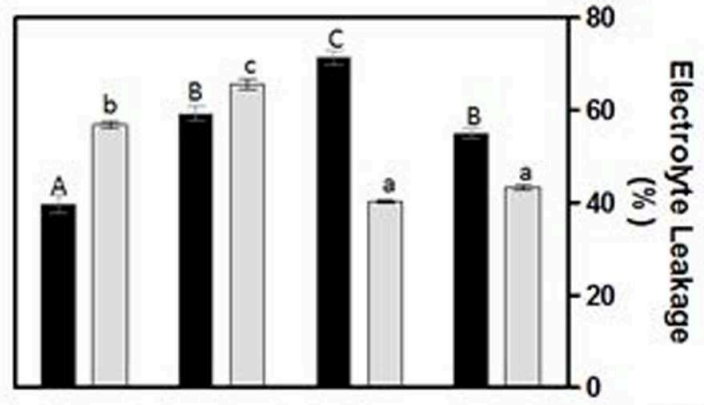

G

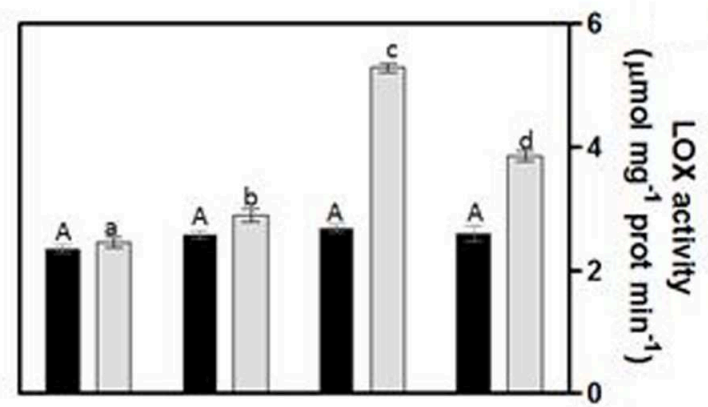

H

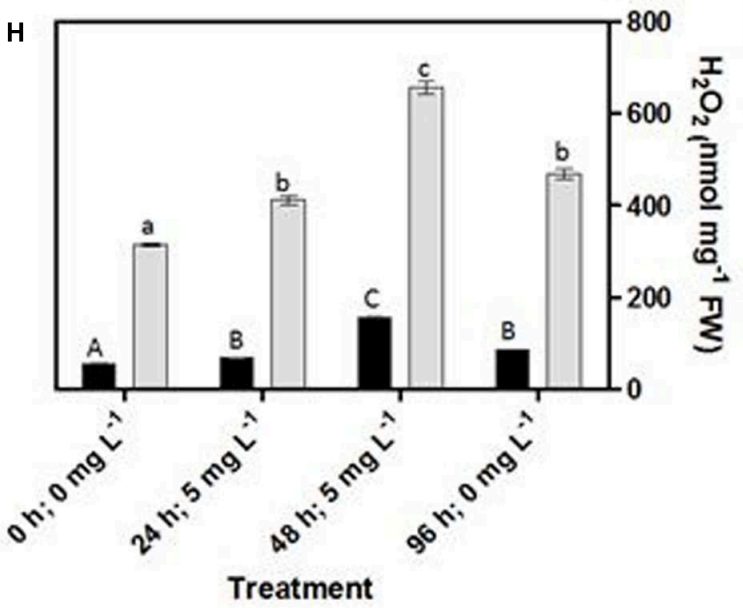

FIGURE 3 | Oxidative stress parameters of rye Al-tolerant (Beira) and Al-sensitive (RioDeva) genotypes. Lipid peroxidation (MDA) content (A,E), EL (B,F), LOX activity $(\mathbf{C}, \mathbf{G})$ and $\mathrm{H}_{2} \mathrm{O}_{2}$ levels $\mathbf{( D , H )}$ in leaves and roots of rye seedlings, respectively. Different uppercase letters represent significant differences between times in Beira, while lowercase letters represent significant differences between times in RioDeva. Values represent mean \pm SD $(n=4)$. 


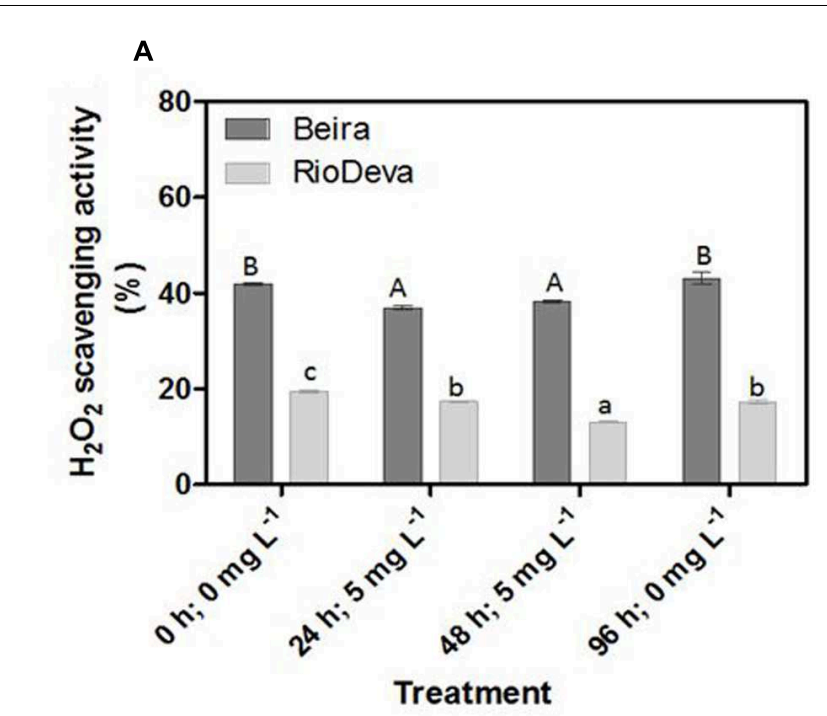

B

FIGURE 4 | Hydrogen peroxide scavenging activity of the methanolic extracts of rye Al-tolerant (Beira) and Al-sensitive (RioDeva) genotypes. Panels represent, $\mathrm{H}_{2} \mathrm{O}_{2}$ scavenging activity $(\mathbf{A}, \mathbf{B})$ the in leaves and roots, respectively. Different uppercase letters represent significant differences between times in Beira, while lowercase letters represent significant differences between times in RioDeva. Values represent mean \pm SD $(n=4)$.

higher in RioDeva seedlings with no significant variations throughout the treatment. A positive correlation was mainly found between ASC content and ASC redox status, in leaves and roots of both genotypes (Figures 6B,I). MDHAR activity was remarkably higher in both organs of RioDeva seedlings and $\mathrm{Al}$ stress significantly increased the catalytic activity of this enzyme, around 12 and 85\%, in leaves and roots, respectively (Figures 6C,J). DHAR activity was extraordinarily higher in both organs of Beira genotype, decreasing 30 and 12\%, in leaves and roots, respectively, at the recovery period (Figures 6D,K). RioDeva leaves presented increased GR activity when compared to Beira and Al treatment resulted in a $29 \%$ decrease of GR activity in leaves of Beira seedlings ( $48 \mathrm{~h} ; 5 \mathrm{mg} \mathrm{L}^{-1}$; Figures 6E,L). After initial exposure to $\mathrm{Al}\left(24 \mathrm{~h} ; 5 \mathrm{mg} \mathrm{L} \mathrm{L}^{-1}\right)$, GSH levels in leaves were very similar in both genotypes, decreasing until the end of the treatment (Figure 6F). The same behavior was observed in roots; however, in this organ GSH levels were higher in Beira genotype (Figure 6M). GSH levels and the GSH redox status were not related in leaves and roots of both genotypes (Figures 6G,N). Tocopherols content and TAC were higher in both organs of Beira genotype (Figures 9A-D). Response of ROS scavenging enzymes and non-enzymatic metabolites in the Al-tolerant and Al-sensitive genotypes, grown in the absence of $\mathrm{Al}$ generally demonstrated that $\mathrm{Al}$ phytotoxicity rather than development processes were responsible for changes in the antioxidant metabolism (Supplementary Figures S3, S4, and S7).

\section{Amino Acid Analyses}

Compared to roots, glutamate levels were generally higher in leaves of both genotypes, presenting similar values throughout the assay, except in the control, where leaves of the tolerant genotype presented about fivefold less content of this amino acid (Supplementary Tables S1 and S2). In Beira leaves, Glu levels increased after the initial exposure to $\mathrm{Al}$ until the end of recovery period. RioDeva leaves manifested similar behavior; however, Glu levels increased $48 \mathrm{~h}$ after $\mathrm{Al}$ exposure (Supplementary Table S1). Roots of Beira seedlings presented higher values of Glu, which increased by $40 \%$ at the end of $\mathrm{Al}$ treatment and remained constant through the recovery period. Al exposure triggered an increase in Glu content in RioDeva roots at the beginning of treatment, which decreased to similar values found in the control (Supplementary Table S2). Unlike Glu, Cys, and Gly levels were higher in roots of both cultivars (Supplementary Tables S1 and S2). Comparing with the respective controls, Cys levels were fivefold higher in leaves of Beira at the end of the $\mathrm{Al}$ treatment, while RioDeva leaves presented an $83 \%$ decrease in this amino acid (Supplementary Table S1). Meanwhile in roots, excepting the control situation, Cys levels were higher in Beira seedlings, increasing sevenfold at early $\mathrm{Al}$ exposure, with values remaining constant until the recovery period. Cys content did not suffer significant variations in RioDeva roots (Supplementary Table S2). Gly levels increased 18\% in leaves of Beira seedlings $24 \mathrm{~h}$ after Al treatment; however, late exposure of seedlings to this HM resulted in 39\% decrease in Gly content that lasted until the end of the experiment (Supplementary Table S1). Early exposure of RioDeva seedlings to $\mathrm{Al}$ resulted in $66 \%$ decrease of Gly content in leaves. For the same genotype and organ Gly content also dropped $82 \%$ at the recovery period. As for roots, Beira and RioDeva seedlings exhibited an increase in Gly levels throughout the experiment (Supplementary Table S2). Serine levels increased $61 \%$ in Beira leaves $24 \mathrm{~h}$ after $\mathrm{Al}$ exposure. Afterward, the concentration of this amino acid decrease until the end of the experiment. Regarding roots, Beira seedlings did not display any significant variations until the recovery period where Ser levels increased $100 \%$, when compared to control. Al treatment resulted in a decrease of Ser levels in RioDeva leaves, 


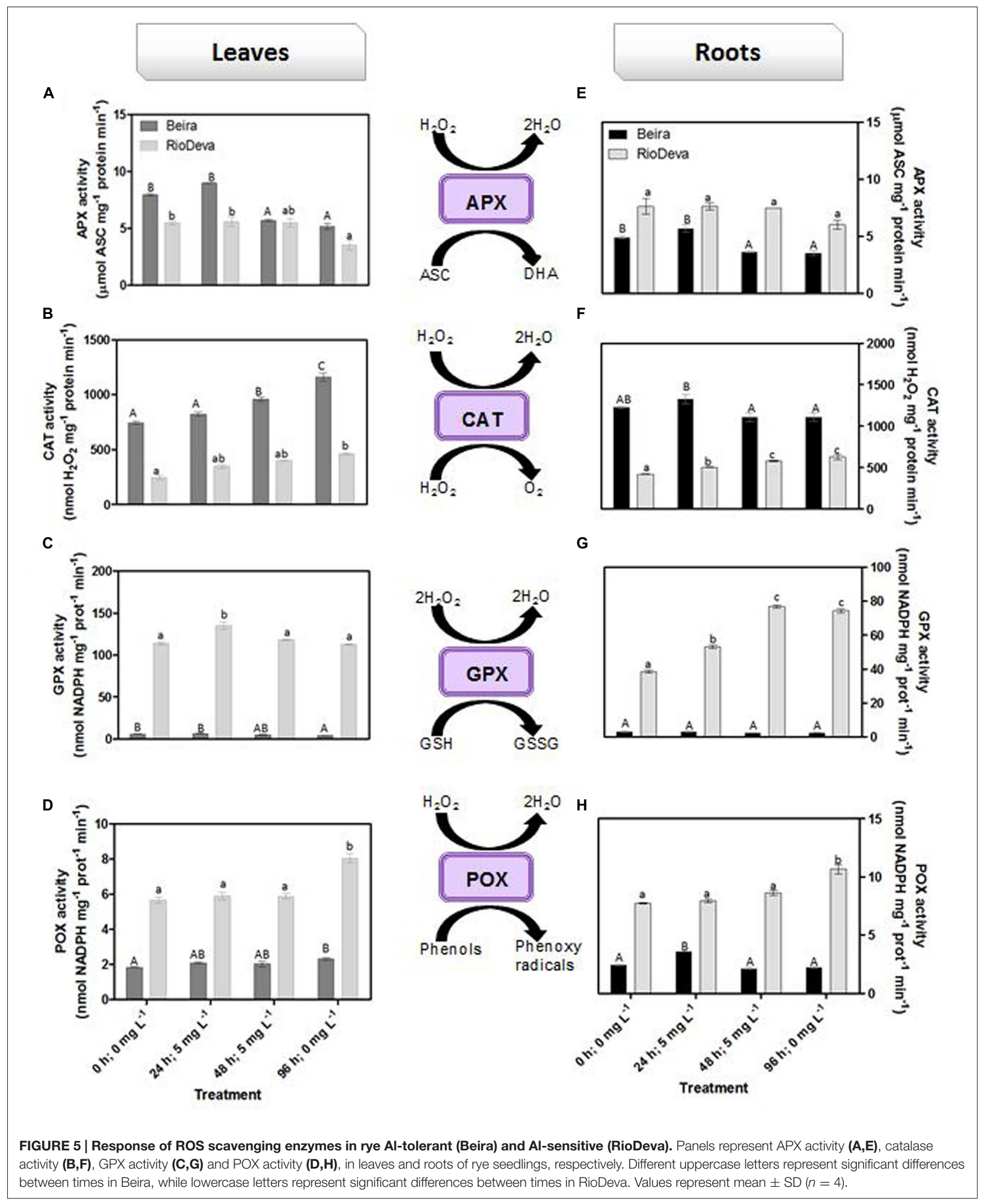




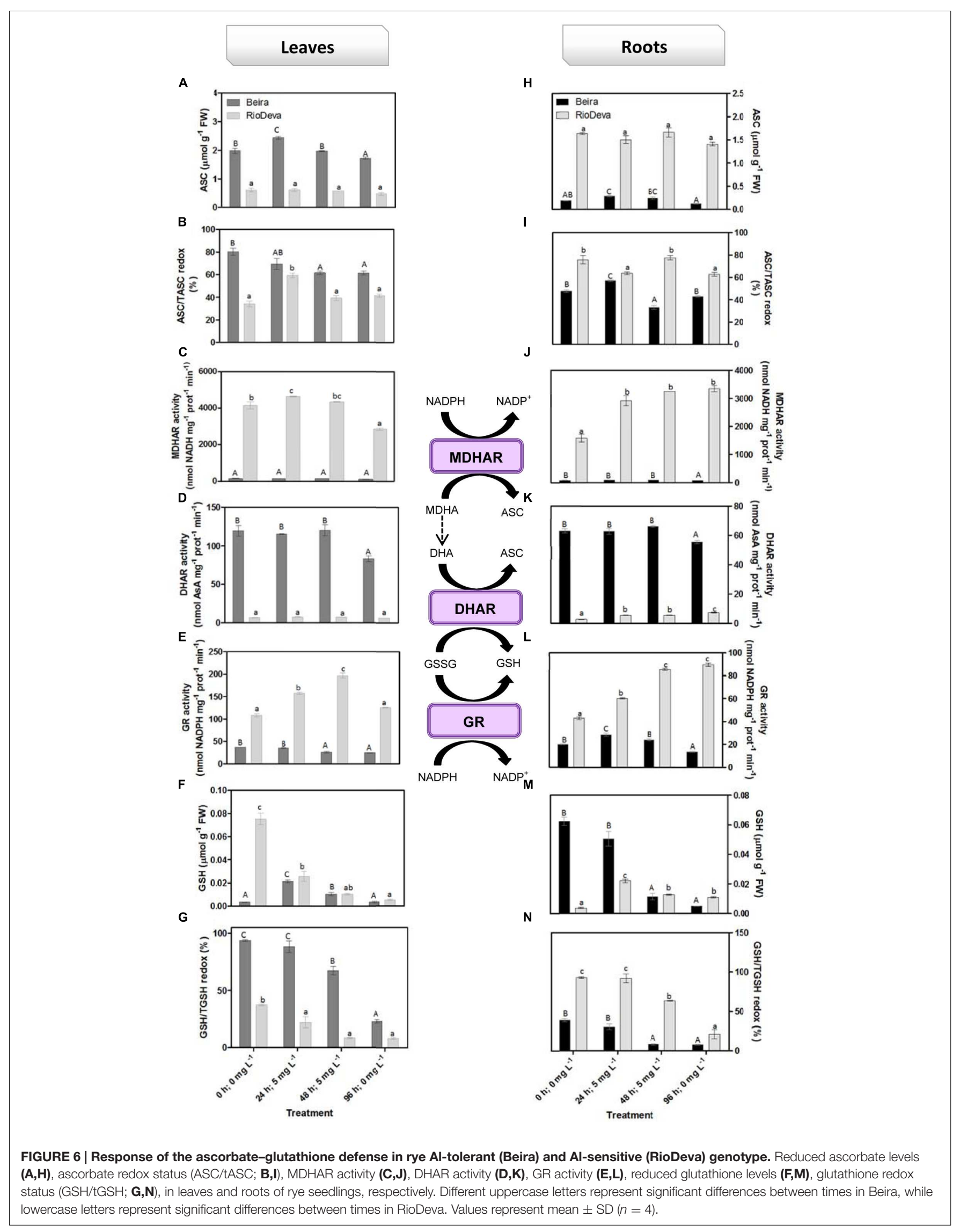




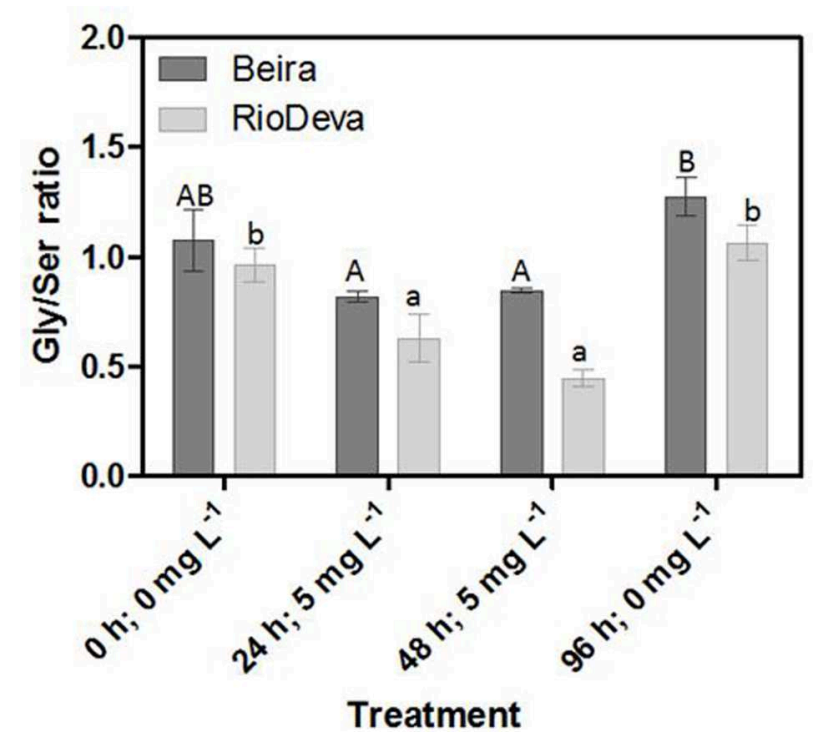

FIGURE 7 | Response of photorespiration in rye Al-tolerant (Beira) and Al-sensitive (RioDeva) genotypes. Panel represent, the ratio of glycine and serine in leaves. Different uppercase letters represent significant differences between times in Beira, while lowercase letters represent significant differences between times in RioDeva. Values represent mean $\pm \operatorname{SD}(n=4)$.

having the opposite effect on roots (Supplementary Tables S1 and S2).

\section{Estimating Photorespiration Activity - Gly/Ser Ratio}

The Gly/Ser ratio, used to estimate the level of photorespiration, decreased by 24 and $45 \%$ in leaves of Beira and RioDeva seedlings, respectively (Figure 7). In leaves of both genotypes Ser/Gly ratio values returned to basal levels in the recovery period. Except for the control situation, roots of Beira seedlings presented higher Gly/Ser ratio, which increased by $66 \%, 24 \mathrm{~h}$ after $\mathrm{Al}$ exposure until the end of the experiment (Figure 7). The Gly/Ser ratio was similar in seedlings grown in the absence of $\mathrm{Al}$ emphasizing the negative effects of this metal in both rye genotypes under short term exposure (Supplementary Figure S5).

\section{Oxalate Levels}

After $48 \mathrm{~h}$ of exposure to $\mathrm{Al}$, oxalate levels were 1.8- and 3fold higher in leaves and roots of Beira seedlings, respectively (Figures 8A,B). No significant fluctuations were found in oxalate levels of RioDeva seedlings (Figure 8A). Regarding RioDeva roots, this $\mathrm{OA}$ increased $47 \%$ in late $\mathrm{Al}$ exposure, and returned to similar values found in control seedlings after the recovery period (Figure 8B). Seedlings grown in the absence of Al showed differences in the oxalate levels, suggesting that $\mathrm{Al}$ effects in the synthesis of this OA maybe potential masked by developmental effects (Supplementary Figure S6).

\section{DISCUSSION}

Beyond affecting global climate, acid rain changes soil chemistry leading to a major accumulation of the highly phytotoxic $\mathrm{Al}^{3+}$ ion that compromises crop growth and yield (Poschenrieder et al., 2008; Reis et al., 2012). Measurements of Al concentration in soil solution is extremely complex and influenced by many factors. Nonetheless, $\mathrm{Al}$ concentrations between 2 and $5 \mathrm{mg} \mathrm{L}^{-1}$ are often found in soil solution. So, in order to simulate field conditions closely as possible, we submitted rye seedlings to a realistic $5 \mathrm{mg} \mathrm{L}^{-1}$ concentration of $\mathrm{Al}^{3+}$, which is already toxic to sensitive plant species (Blamey et al., 2015). To uncover the mechanisms underlying rye oxidative metabolism after $\mathrm{Al}$ exposure we analyzed its impact on productivity, physiology and biochemical pathways.

\section{Effects of Al Toxicity on Seedling Growth and Development}

$\mathrm{Al}$ treatment affected biomass production in roots and leaves of RioDeva seedlings. Also, after the recovery period total root length was significantly reduced in this genotype. Together, these results are in agreement with the data obtained in the aluminum tolerance screening assay corroborating the previous classification of RioDeva cultivar as an Al-sensitive genotype (Gallego and Benito, 1997). Unlike RioDeva, Beira genotype seemed to overcome Al toxicity under short-term exposure, since biomass increased throughout the treatment. Considering that all the seedlings tested to $\mathrm{Al}$ tolerance presented root regrowth, Beira genotype was for the first time classified as Al-tolerant. Cell division and expansion are well-known processes inherent to plant growth and development. Recent studies performed in maize, confirmed that Al-induced inhibition of root growth can be due to a reduction in cell division, shortly after $\mathrm{Al}$ exposure (Doncheva et al., 2005). However, it is mostly believed that $\mathrm{Al}$ restrains cell elongation during the initial stages of root growth inhibition (Matsumoto, 2000; Horst et al., 2010). Al influences directly cell growth by binding itself to pectin molecules and DNA as well as indirectly by manipulating biochemical pathways that influence cell division and expansion. Our results predict that expansion of already divided cells plays a central role in root elongation of rye seedlings, although more detailed research is required to support this hypothesis. Cell growth is directly or indirectly affected by ascorbate and its oxidation products (MDA; DHA), as well by the enzymatic activity of peroxidases like APX (Davey et al., 2000).

In roots of Beira seedlings, higher APX activity contributes to reduce the availability of $\mathrm{H}_{2} \mathrm{O}_{2}$, preventing lignification of cell walls, resulting in looser cell walls (Yamamoto et al., 2003). DHA levels were higher in this genotype (data not shown) stimulating cell expansion since this radical prevents cross linking of structural proteins with hemicelluloses and polygalacturonases (Smirnoff, 1996). Additionality, some of the oxalate quantified in roots of Beira, may have been incorporated in calcium oxalate crystals, increasing cell wall plasticity (Smirnoff, 1996). ASC is related to cell division in plants. Reports showed that ASC controls transition from G1 to S phase, enhancing cell division 
A

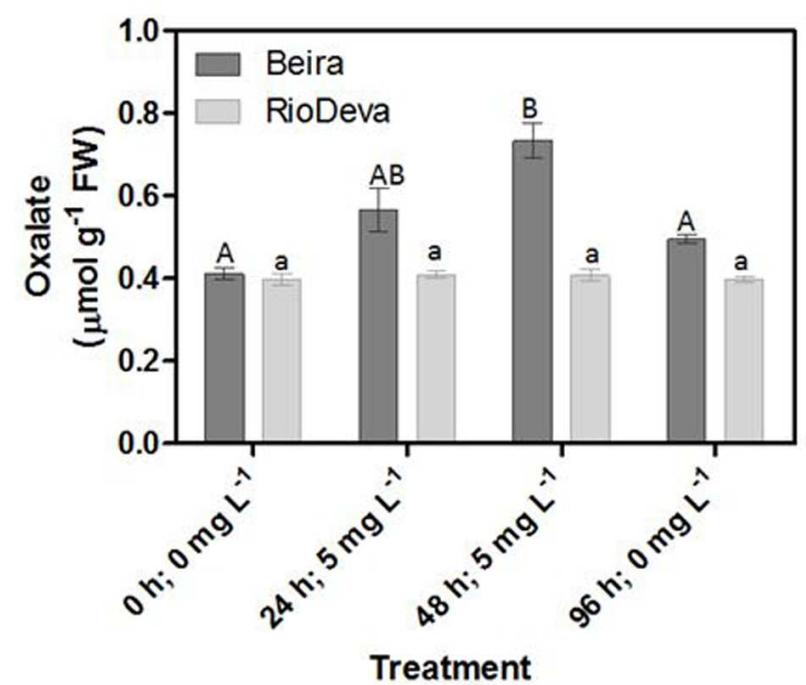

B

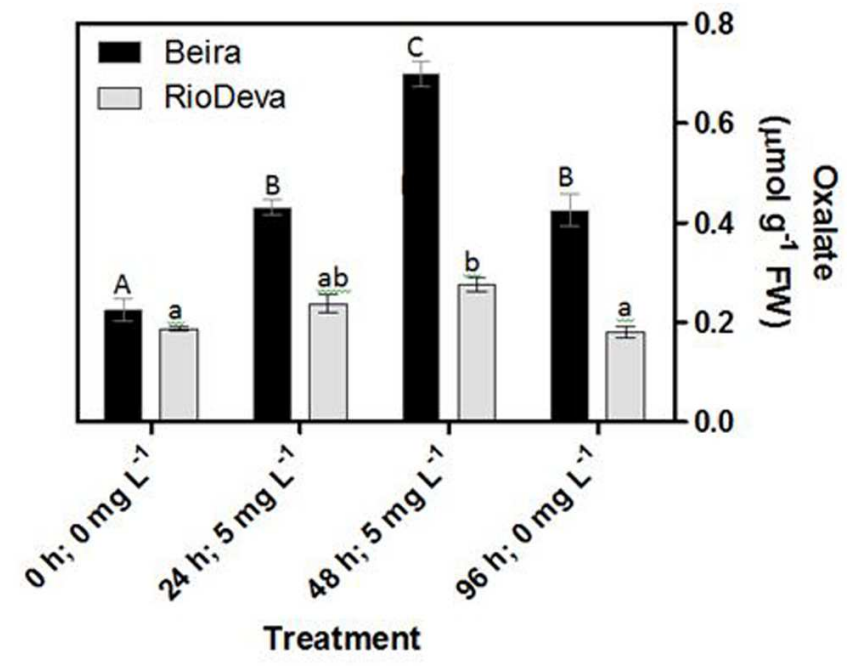

FIGURE 8 | Oxalate content in rye Al-tolerant and Al-sensitive genotypes. Panels represent organic acid levels (A,B) in leaves and roots, respectively. Different uppercase letters represent significant differences between times in Beira, while lowercase letters represent significant differences between times in RioDeva. Values represent mean $\pm \operatorname{SD}(n=4)$.

and therefore root growth (Kerk and Feldman, 1995; Potters et al., 2000). Our results, also suggest the involvement of ASC in cell cycle progression in rye roots. Through the Eriochrome cyanine $R$ staining test we observed that $\mathrm{Al}$ accumulated in the root apex of RioDeva roots caused irreversible damage to the root apical meristematic and cap cells, making impossible any kind of root regrowth after the recovery period. Also, due to this higher accumulation in roots of RioDeva genotype, $\mathrm{Al}$ can bind itself to the pectin matrix resulting in cell wall strengthening. These results are consistent with other reports of Al-induced root growth inhibition (Van et al., 1994; Tabuchi and Matsumoto, 2001; Ma et al., 2004; Eticha et al., 2005; Yang et al., 2008).

\section{Al and Cell Redox Homeostasis}

Heavy metals (HMs) induce oxidative stress either by triggering $\mathrm{H}_{2} \mathrm{O}_{2}$ and ROS formation or by decreasing enzymatic and nonenzymatic antioxidants (Sharma et al., 2012). LP is considered a biomarker of metal-induced oxidative stress and lipid peroxy radicals are formed either through enzymatic processes (LOX) and/or by non-enzymatic (ROS) oxidation of membrane lipids, resulting in the major accumulation of $\mathrm{MDA}$ (Foyer and Noctor, 2005; Sharma et al., 2012). Lipid oxidation of biological membranes can lead to leakage of cellular components and therefore, EL assays are also commonly used to estimate membrane stability under stressful situations. LP, detected through MDA content, increased in both organs of RioDeva seedlings after Al exposure. Giannakoula et al. (2008) found similar results in maize, since $\mathrm{Al}$ treatment enhanced oxidation of membrane lipids in the sensitive line, while the tolerant one did not exhibited significant variations on MDA levels. Also, rice, triticale and wheat increased MDA contents after $\mathrm{Al}$ exposure emphasizing LP as a signal of Al toxicity in cereals (Hossain et al., 2005; Sharma and Dubey, 2007; Liu et al., 2008).

Changes in EL and LOX activity were found to be positively correlated with MDA accumulation in both organs of Beira and RioDeva genotypes, suggesting that LOX contributed in a largescale to the formation of lipid peroxy radicals. Some reports showed that $\mathrm{Al}$ can change membrane lipid architecture leading to modifications in membrane permeability. It is also known that changes in membrane permeability are dependent of the plant tolerance to Al (Levine et al., 1994; Stab and Horst, 1995; Kochian and Jones, 1997; Willekens, 1997). Our results suggest that biological membranes are one of the targets of oxidative stress in rye under $\mathrm{Al}$ short-term exposure. As described, RioDeva seedlings accumulated more $\mathrm{Al}$ in its root apex than Beira's, and this could be the major cause for the enhanced LP and EL observed in this genotype. A close relationship between LP and inhibition of the root elongation rate was already observed in soybean (Cakmak and Horst, 1991). Since Al is a nonredox metal, it cannot catalyze redox reactions inherent to the LP process. Therefore, it has been demonstrated that Alinduced rigidity of membranes facilitates the initiation of LP by the binding of iron $\left(\mathrm{Fe}^{2+}\right)$ to membrane lipids (Oteiza, 1994; Ikegawa et al., 2000). Moreover, Al exposure can activate LOXs in plant root cells (Wang and Yang, 2005), which can explain the enhanced LP observed in RioDeva roots. Al exposure results in the impairment of antioxidant systems resulting in ROS accumulation, such as $\mathrm{H}_{2} \mathrm{O}_{2}$, which can culminate in the oxidation of membrane lipids (Yamamoto et al., 2002; Achary et al., 2008; Ma et al., 2012; Xu et al., 2012). These data support our results since $\mathrm{H}_{2} \mathrm{O}_{2}$ levels were higher in roots of RioDeva when compared to the tolerant genotype. Both genotypes presented higher $\mathrm{H}_{2} \mathrm{O}_{2}$ accumulation in leaves when 


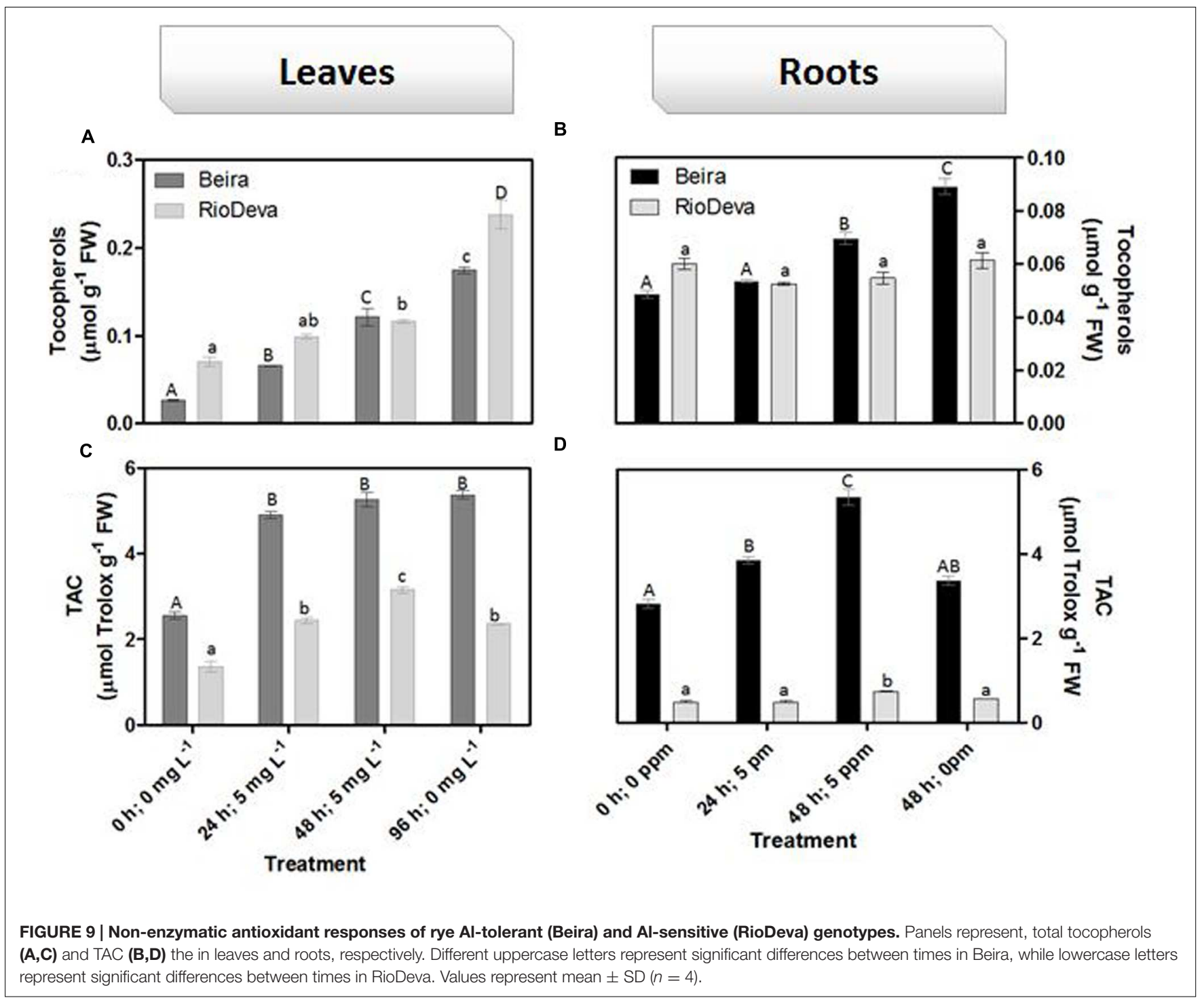

compared to roots, which it is not surprising since due to photosynthesis electron transfer reactions are constantly leading to ROS formation (Sharma et al., 2012). After Al being removed in the recovery period, $\mathrm{H}_{2} \mathrm{O}_{2}$ levels decreased significantly in leaves and roots of both genotypes. This strongly suggests that $\mathrm{H}_{2} \mathrm{O}_{2}$ production results from direct exposure of rye seedlings to $\mathrm{Al}$ under short-term exposure. Undoubtedly, our results showed that the reduced $\mathrm{H}_{2} \mathrm{O}_{2}$ scavenging activity in both organs of RioDeva seedlings favored $\mathrm{H}_{2} \mathrm{O}_{2}$ accumulation leading to an imbalance on the redox homeostasis resulting in the establishment of oxidative stress in this genotype.

In order to protect themselves against oxidative damage, plants developed a powerful and complex antioxidant network comprising of both enzymatic and non-enzymatic constituents (Mittler, 2002; Foyer and Noctor, 2005; Gill and Tuteja, 2010). SOD, catalase, and APX represent the major ROS-scavenging enzymes controlling the basal levels of anion superoxide radicals $\left(\mathrm{O}_{2}{ }^{\bullet-}\right.$ ) and $\mathrm{H}_{2} \mathrm{O}_{2}$ (Bowler et al., 1992; Sharma et al., 2012). $\mathrm{H}_{2} \mathrm{O}_{2}$ is produced by plants under normal, non-stressful conditions, through several metabolic processes playing a key role as a signaling molecule in several physiological processes and resistance tolerance (Quan et al., 2008). Enzymatic assays in roots of both genotypes showed that APX does not seems to play a central role in $\mathrm{H}_{2} \mathrm{O}_{2}$ scavenging of rye seedlings after $\mathrm{Al}$ exposure, because despite of its higher activity in RioDeva roots, no significant fluctuations were observed in its catalytic activity that could explain the significant changes in the $\mathrm{H}_{2} \mathrm{O}_{2}$ levels observed in this organ and genotype. This hypothesis was reinforced by the APX activity observed in leaves. Our results also demonstrated that late $\mathrm{Al}$ exposure $\left(48 \mathrm{mg} \mathrm{L}^{-1}\right)$ decreased APX activity in both organs of Beira genotype. Here, Beira seedlings can compensate APX loss with an increase in CAT activity. Since CAT has a very fast turnover rate, but a much lower affinity for $\mathrm{H}_{2} \mathrm{O}_{2}$ than APX it is generally accepted that this enzyme is involved in removal of $\mathrm{H}_{2} \mathrm{O}_{2}$ overproduced during oxidative stress, while APX is responsible for the fine modulation 
of $\mathrm{H}_{2} \mathrm{O}_{2}$ involved in signalization pathways (Bowler et al., 1992; Willekens, 1997; Mittler, 2002). Du et al. (2010) observed that in roots of soybean APX activity increased proportionality with $\mathrm{Al}$ concentration and treatment duration. Al-tolerant wheat genotype also presented higher APX activity after short time exposure (Xu et al., 2012) and rice increased APX activity under long term exposure (Sharma and Dubey, 2007). The same behavior was posteriorly found in rice plants 3 weeks after Al exposure (Silva et al., 2013). Al tolerance mechanisms are different between plant species, organs and tissues, which constitutes a perfectly reasonable explanation for the variation observed between the studies mentioned above (Boscolo et al., 2003).

Opposite to CAT, GPX, and POX played major roles in the first line of $\mathrm{H}_{2} \mathrm{O}_{2}$ detoxification in both leaves and roots of RioDeva seedlings. Under short term exposure, $\mathrm{Al}$ is also responsible for increased GPX and POX activities in other cereals such barley, wheat and rice (Meriga et al., 2004; Šimonovičová et al., 2004; Hossain et al., 2005). Our data demonstrate that peroxidases act as alternative and much more efficient enzymes in $\mathrm{H}_{2} \mathrm{O}_{2}$ detoxification then CAT in the RioDeva genotype. Also, duration of $\mathrm{Al}$ treatment seems to influence the response of mechanisms involved in plant protection against oxidative stress. Photorespiration is recently considered an imperative process in abiotic stress responses, since it can modulate the levels of ROS and $\mathrm{H}_{2} \mathrm{O}_{2}$ production (Voss et al., 2013). The glycine:serine ratio, used to estimate photorespiration activity (Kebeish et al., 2007) was lower in the RioDeva genotype, predicting a lower $\mathrm{H}_{2} \mathrm{O}_{2}$ production in its leaves, which does not reflect our $\mathrm{H}_{2} \mathrm{O}_{2}$ quantifications. This situation is easily understandable by the fact that $\mathrm{H}_{2} \mathrm{O}_{2}$ is produced not only in peroxisomes during photorespiration, but also in chloroplasts, cytoplasm and mitochondrias through electron transport chain reactions. $\mathrm{H}_{2} \mathrm{O}_{2}$ is also produced in plasma membranes by NADPH oxidase activity and in the extracellular matrix, by $\mathrm{pH}$-dependent cell wall peroxidases, germins, germin-like oxlate oxidases, and amine oxidases (Slesak et al., 2007). Reduced membrane damage in Beira roots could also be due to the accumulation of the lipophilic tocopherols which are membrane-bound antioxidants. In leaves, tocopherol levels were higher in the RioDeva seedlings, suggesting that this genotype tried to overcome Al toxicity in leaves. Consistent with this results an increased antioxidant capacity in leaves and roots of the tolerant Beira genotype was observed.

\section{Can MDHAR and DHAR Activities Be the Key of Differential Al Tolerance in Rye Genotypes?}

In plants, the ASC-GSH is crucial for the control of ROS levels and cellular redox homeostasis (Dubey, 2011). APX activity was higher in RioDeva roots as well as the ascorbate levels. Ascorbate is a potent antioxidant present in the apoplast of cells, protecting then from $\mathrm{H}_{2} \mathrm{O}_{2}$ and ROS generated during oxidative stress (Yin et al., 2010). Al accumulation was higher in roots of RioDeva seedlings, and since $30-90 \%$ of the total Al uptake by roots is found mainly in the apoplast of peripheral cell roots (Liu et al., 2008), it was noticed that this sensitive genotype tries to overcome $\mathrm{Al}$ toxicity under short term exposure by increasing total ascorbate content, in an effort to adapt to the stress situation. MDHAR specific activity was much higher than DHAR after Al exposure, suggesting that in this genotype, the MDHA radicals produced by APX in $\mathrm{H}_{2} \mathrm{O}_{2}$ reduction to water, were immediately transferred back into ASC via enzymatic (MDHAR) or nonenzymatic (spontaneous disproportion) processes. Reinforce this hypothesis; we observed that GR increased through the $\mathrm{Al}$ treatment, providing reduced gluthatione which served as an electron donor to the DHAR to reduced dehydroascorbate back into ASC, because even when a fast disproportion of the MDHA radical occurs some DHA is always produced.

Together these results suggest that the Al-sensitive RioDeva genotype tries to counteract the negative effects of $\mathrm{Al}$ toxicity in roots by increasing the ASC content, although without success because oxidative stress biomarkers and biomass were deeply affected by $\mathrm{Al}$ exposure. Beira roots seemed to cope with $\mathrm{Al}$ toxicity by another more effective strategy. In this genotype, despite of its higher catalytic activity when compared to MDHAR, DHAR enzyme did not exhibit significant variations after the Al treatment. This fact, combined with the poor ASC regeneration and lower GR activity, suggests that DHA generated through APX activity is being converted into oxalate and tartarate, lowering $\mathrm{Al}$ concentration in root tissues by the formation of stable and non-toxic Al-oxalate conjugates that are posteriorly translocated into the vacuoles. Supporting this hypothesis is the enhanced accumulation of oxalate in roots of this Al-tolerant genotype after $\mathrm{Al}$ exposure. Our results are in accordance with other reports obtained in maize (Klug et al., 2011) and buckwheat (Zhu et al., 2015 and references).

Regarding leaves the same behavior was observed with the exception that in this organ Beira genotype is also investing in the ASC regeneration, thus providing an extra protection for the photosynthetic apparatus against the Al toxicity. Another fact is that $\mathrm{Al}$ affected not only the GR activity in leaves and roots of both genotypes, but also the biosynthetic pathway of the amino acids that constitute GSH. We observed that serine levels were close to those of glycine, reinforcing the fact that GSH main coexist in two different tripeptides in rye (Rauser, 1999).

\section{CONCLUSION}

We observed that rye $\mathrm{Al}$ tolerance under short term exposure is dependent on the genotype and plant organs, and that the response of the antioxidant system comprises changes in proline and ascorbate levels, its oxidation products and its regenerating enzymes, being key points for the survival of rye seedlings in early development stages in $\mathrm{Al}$ contaminated soils.

\section{AUTHOR CONTRIBUTIONS}

AS conceived the project and experiments and wrote the article with contributions of all authors; HA and AS conducted all the 
experiments; $\mathrm{AH}$ supervised the experiments and revised the manuscript; JT supervised the experiments and revised the manuscript; MM conceived the project and supervised the experiments and revised the manuscript; FF conceived the project and supervised the experiments and revised the manuscript.

\section{FUNDING}

This research was supported by the FCT (Fundação para a Ciência e Tecnologia; grant ref. BD/84651/2012).

\section{REFERENCES}

AbdElgawad, H., De Vos, D., Zinta, G., Domagalska, M. A., Beemster, G. T. S., and Asard, H. (2015). Grassland species differentially regulate proline concentrations under future conditions: an integrated biochemical and modeling approach. New Phytol. 208, 354-369. doi: 10.1111/nph.13481

Achary, V. M., Jena, S., Panda, K. K., and Panda, B. B. (2008). Aluminum induced oxidative stress and DNA damage in root cells of Allium cepa L. Ecotoxicol. Environ. Safety 70, 300-310. doi: 10.1016/j.ecoenv.2007.10.022

Aebi, H. (1984). Catalase in vitro. Methods Enzymol. 105, 121-126. doi: $10.1016 /$ S0076-6879(84)05016-3

Aniol, A., and Gustafson, J. P. (1984). Chromosome location of genes controlling aluminum tolerance in wheat, rye and triticale. Can. J. Genet. Cytol. 26, 701-705. doi: 10.1007/s13353-013-0170-0

Benzie, I. F. F., and Szeto, Y. T. (1999). Total antioxidant capacity of teas by the ferric reducing/antioxidant power assay. J. Agric. Food Chem. 47, 633-636. doi: $10.1021 / \mathrm{jf} 9807768$

Blamey, F. P. C., Kopittke, P. M., Wehr, B., and Menzies, N. W. (2015). "Aluminum," in Handbook of Plant Nutrition, 2nd Edn, eds A. V. Barker and D. J. Pilbeam (Boca Florida: CRC Press), 576-577.

Boscolo, P. R. S., Menossi, M., and Jorge, R. A. (2003). Aluminum-induced oxidative stress in maize. Phytochemistry. 62, 181-189. doi: 10.1016/S00319422(02)00491-0

Bowler, C., Van Montagu, M., and Inzé, D. (1992). Superoxide dismutase and stress tolerance. Annu. Rev. Plant Physiol. Plant Mol. Biol. 43, 83-116. doi: 10.1146/annurev.pp.43.060192.000503

Brunner, I., and Sperisen, C. (2013). Aluminum exclusion and aluminum tolerance in woody plants. Front. Plant Sci. 4:172. doi: 10.3389/fpls.2013.00172

Cakmak, I., and Horst, J. H. (1991). Effects of aluminum on lipid peroxidation, superoxide dismutase, catalase and peroxidase activities in root tips of soybean (Glycine max). Physiol. Plant. 83, 463-468. doi: 10.1034/j.13993054.1991.830320.x

Cassiolato, M. E., Meda, A. R., Pavan, M. A., Miayazama, M., and Oliveira, J. C. (2000). Evaluation of oat extracts on the efficiency of lime in soil. Braz. Arch. Biol. Technol. 43, 533-536. doi: 10.1590/S1516-89132000000500014

Davey, M. W., Van Montag, M., Inzé, D., Sanmartin, M., Kanellis, A., Smirnoff, N., et al. (2000). Plant L-ascorbic acid: chemistry, function, metabolism, bioavailability and effects of processing. J. Food Sci. Agric. 80, 825-860. doi: 10.1002/(SICI) 1097-0010(20000515)80:7<825::AID-JSFA598> 3.0.CO;2-6

Doncheva, S., Amenós, M., Poschenrieder, C., and Barceló, J. (2005). Root cell patterning: a primary target for aluminum toxicity in maize. J. Exp. Bot. 56, 1213-1220. doi: $10.1093 / \mathrm{jxb} /$ eri115

Drotar, A., Phelps, P., and Fall, R. (1985). Evidence for glutathione-peroxidase activities in cultured plant-cells. Plant Sci. 42, 35-40. doi: 10.1016/01689452(85)90025-1

Du, B., Nian, H., and Zhang, Z. (2010). Effects of aluminum on superoxide dismutase and peroxidase activities, and lipid peroxidation in the roots and calluses of soybeans differing in aluminum tolerance. Acta Physiol. Plant. 32, 883-890. doi: 10.1007/s11738-010-0476-z

Dubey, R. S. (2011). "Metal toxicity, oxidative stress and antioxidative defense system in plants," in Reactive Oxygen Species and Antioxidants in Higher Plants, Chap. 9, ed. S. D. Gupta (Enfield: Science Publishers), 178-203.

\section{ACKNOWLEDGMENTS}

The authors would like to thank Prof. Dr. Aires Oliva-Teles for the critical review and assistance on the statistical experimental design. We thank Vítor Silva for his help in formatting the figures of the manuscript.

\section{SUPPLEMENTARY MATERIAL}

The Supplementary Material for this article can be found online at: http://journal.frontiersin.org/article/10.3389/fpls.2016.00685

Eticha, D., Stab, A., and Horst, W. J. (2005). Cell-wall pectin and its degree of methylation in the maize root-apex: signifance for genotypic differences in aluminum resistance. Plant Cell Environ. 28, 1410-1420. doi: 10.1111/j.13653040.2005.01375.x

Fontecha, G., Silva-Navas, J., Benito, C., Mestres, M. A., Espino, F. J., HernándezRiquer, M. V., et al. (2007). Candidate gene identification of na aluminumactivated organic acid transporter gene at the Alt4 locus for aluminum tolerance in rye (Secale cereal L.). Theor. Appl. Genet. 114, 249-260. doi: 10.1007/s00122006-0427-7

Foyer, C. H., and Noctor, G. (2005). Oxidant and antioxidant signaling in plants: a re-evaluation of the concept of oxidative stress in a physiological context. Plant Cell Environ. 28, 1056-1071. doi: 10.1111/j.1365-3040.2005.01327.x

Foyer, C. H., and Noctor, G. (2011). Ascorbate and glutathione: the heart of the redox hub. Plant Physiol. 155, 2-18. doi: 10.1104/pp.110.167569

Gallego, F. J., and Benito, C. (1997). Genetic control of aluminum tolerance in rye (Secale cereal L.). Theor. Appl. Genet. 95, 393-399. doi: 10.1007/s0012200 50575

Giannakoula, A., Moustakas, M., Mylona, P., Papadakis, I., and Yupsanis, T. (2008). Aluminum tolerance in maize is correlated with increased levels of mineral nutrients, carbohydrates and proline, and decreased levels of lipid peroxidation and $\mathrm{Al}$ accumulation. J. Plant Physiol. 165, 385-396. doi: 10.1016/j.jplph.2007.01.014

Gill, S. S., and Tuteja, N. (2010). Reactive oxygen species and antioxidant machinery in abiotic stress tolerance in crop plants. Plant Physiol. Biochem. 48, 909-930. doi: 10.1016/j.plaphy.2010.08.016

Hede, A. R., Skovmand, B., Ribaut, J. M., Gonzalez-de-Leon, D., and Stlen, O. (2002). Evaluation of aluminum tolerance in a spring rye collection by hydroponic screening. Plant Breed. 121, 241-248. doi: 10.1046/j.14390523.2002.00706.x

Horst, W. J., Wang, Y., and Eticha, D. (2010). The role of the apoplast in aluminuminduced inhibition of root elongation and in aluminum resistance of plants: a review. Ann. Bot. 106, 185-197. doi: 10.1093/aob/mcq053

Hossain, M. A., Hossain, A. K. M. Z., Kihara, T., Koyama, H., and Hara, T. (2005). Aluminum-induced lipid peroxidation and lignin deposition are associated with an increase in $\mathrm{H}_{2} \mathrm{O}_{2}$ generation in wheat seedlings. Soil Sci. Plant Nutri. 51, 223-230. doi: 10.1111/j.1747-0765.2005.tb00026.x

Huang, C. F., Yamaji, N., Mitani, N., Yano, M., Nagamura, Y., and Ma, J. F. (2009). A bacterial-type $\mathrm{ABC}$ transporter is involved in aluminum tolerance in rice. Plant Cell 21, 655-667. doi: 10.1105/tpc.108.064543

Ikegawa, H., Yamamoto, Y., and Matsumoto, H. (2000). Responses to aluminum of suspension-cultured tobacco cells in a simple calcium solution. Soil Sci. Plant Nutri. 46, 503-514.

Kebeish, R., Niessen, M., Thiruveedhi, K., Bari, R., Hirsch, H. J., Rosenkranz, R., et al. (2007). Chloroplastic photorespiratory bypass increases photosynthesis and biomass production in Arabidopsis thaliana. Nat. Biotechnol. 25, 593-599. doi: $10.1038 /$ nbt1299

Kerk, N. M., and Feldman, L. J. (1995). A biochemical-model for the initiation and maintenance of the quiescent center - Implications for organization of root-meristems. Development 121, 2825-2833.

Klug, B., Specht, A., and Horst, W. J. (2011). Aluminum localization in root tips of the aluminum-accumulating plant species buckwheat (Fagopyrum esculentum Moench). J. Exp. Bot. 62, 5453-5462. doi: 10.1093/jxb/err222 
Kochian, L. V., Hoeckenga, O. A., and Piñeros, M. A. (2004). How do crop plants tolerate acid soils? Mechanisms of aluminum tolerance and phosphorus efficiency. Annu. Rev. Plant Biol. 55, 459-493. doi: 10.1146/annurev.arplant.55.031903.141655

Kochian, L. V., and Jones, D. L. (1997). "Aluminum toxicity and resistance in plants," in Research Issues in Aluminum Toxicity, eds R. Yokel and M. Golub (Washington, DC: Taylor and Francis), 69-70.

Kumar, K. B., and Khan, P. A. (1982). Peroxidase and polyphenol oxidase in excised ragi (Eleusine coracana cv. PR 202) leaves during senescence. Indian J. Exp. Biol. $20,412-416$.

Kuo, M. C., and Kao, C. H. (2003). Aluminum effects on lipid peroxidation and antioxidative enzyme activities in rice leaves. Biol. Plant. 46, 149-152. doi: 10.1007/s10646-013-1058-9

Levine, A., Tenhaken, R., Dixon, R., and Lamb, C. (1994). H2O2 from the oxidative burst orchestrates the plant hypersensitive disease resistance response. Cell 79, 583-593. doi: 10.1016/0092-8674(94)90544-4

Liu, Q., Yang, J. L., He, L. S., Li, Y. Y., and Zheng, S. J. (2008). Effect of aluminum on cell wall, plasma membrane antioxidants and root elongation in triticale. Biol. Plant. 52, 87-92. doi: 10.1007/s10535-008-0014-7

Lowry, H. O., Rosebrough, N. J., Far, A. L., and Randall, R. J. (1951). Protein measurement with the folin phenol reagent. Crop Science. 40, 503-510.

Lutts, S., Kinet, J. M., and Bouharmont, J. (1996). NaCl-induced senescence in leaves of rice (Oryza sativa L.) cultivars differing in salinity resistance. Ann. Bot. 78, 389-398. doi: 10.1006/anbo.1996.0134

Ma, B., Gao, L., Zhang, H., Cui, J., and Shen, Z. (2012). Aluminum-induced oxidative stress and changes in antioxidant defenses in the roots of rice varieties differing in Al tolerance. Plant Cell Rep. 31, 687-696. doi: 10.1007/s00299-011$1187-7$

Ma, J. F. (2000). Role of organic acids in detoxification of aluminum in higher plants. Plant Cell Physiol. 41, 383-390. doi: 10.1093/pcp/41.4.383

Ma, J. F., Ryan, P. R., and Delhaize, E. (2001). Aluminum tolerance in plants and the complexing roles of organic acids. Trends Plant Sci. 6, 273-278. doi: 10.1016/S1360-1385(01)01961-6

Ma, J. F., Shen, R. F., Nagao, S., and Tanimoto, E. (2004). Aluminum targets elongating cells by reducing cell wall extensibility in wheat roots. Plant Cell Physiol. 45, 583-589. doi: 10.1093/pcp/pch060

Matsumoto, H. (2000). Cell biology of aluminum toxicity and tolerance in higher plants. Int. Rev. Cytol. 200, 1-46. doi: 10.1016/S0074-7696(00)00001-2

Meriga, B., Reddy, B. K., Rao, K. R., Reddy, L. A., and Kishor, P. B. K. (2004). Aluminium-induced production of oxygen radicals, lipid peroxidation and DNA damage in seedlings of rice (Oryza sativa). J. Plant Physiol. 161, 63-68. doi: 10.1078/0176-1617-01156

Mittler, R. (2002). Oxidative stress, antioxidants and stress tolerance. Trends Plant Sci. 9, 405-410. doi: 10.1016/S1360-1385(02)02312-9

Murshed, R., Lopez-Lauri, F., and Sallanon, H. (2008). Microplate quantification of enzymes of the plant ascorbate-glutathione cycle. Anal. Biochem. 383, 320-322. doi: 10.1016/j.ab.2008.07.020

Ngonda, F. (2013). In vitro antioxidant activity and free radical scavenging potential of roots of Malawian Trichodesma zeylanicumm (burm. F.). Asian J. Biomed. Pharm. Sci. 3, 21-25.

Noctor, G., Mhamdi, A., Chaouch, S., Han, Y., Neukermans, J., Marquez-Garcia, B., et al. (2012). Glutathione in plants: an integrated overview. Plant Cell Environ. $35,454-484$

Oteiza, P. I. (1994). A mechanism for the simulatory effect of aluminum on iron-induced lipid peroxidation. Arch. Biochem. Biophys. 308, 347-379.

Poschenrieder, C., Gunse, B., Corrales, I., and Barcelo, J. (2008). A glance into aluminum toxicity and resistance in plants. Sci. Total Environ. 400, 356-368. doi: $10.1016 /$ j.scitotenv.2008.06.003

Potters, G., Horemans, N., Bellone, S., Caubergs, R. J., Trost, P., Guisez, Y., et al. (2004). Dehydroascorbate influences the plant cell cycle through a glutathione-independent reduction mechanism. Plant Physiol. 134, 1479-1487. doi: 10.1104/pp.103.033548

Potters, G., Horemans, N., Caubergs, R. J., and Asard, H. (2000). Ascorbate and dehydroascorbate influence cell cycle progression in a tobacco cell suspension. Plant Physiol. 124, 17-20. doi: 10.1104/pp.124.1.17

Quan, L. J., Zhang, B., Shi, W. W., and Li, H. Y. (2008). Hydrogen peroxide in plants: a versatile molecule of the reactive oxygen species network. J. Integr. Plant Biol. 50, 2-18. doi: 10.1111/j.1744-7909.2007.00599.x
Ramakrishna, B., and Rao, S. S. R. (2012). 24-Epibrassinolide alleviated zincinduced oxidative stress in radish (Raphanus sativues $\mathrm{L}$.) seedlings by enhancing antioxidative system. Plant Growth Regul. 68, 249-259. doi: 10.1007/s10725012-9713-3

Rauser, W. E. (1999). Structure and function of metal chelators produced by plants: the case for organic acids, amino acids, phytin and metallothioneins. Cell Biochem. Biophys. 31, 19-48. doi: 10.1007/BF02738153

Reis, S., Grennfelt, P., Klimont, Z., Amann, M., ApSimon, H., Hettelingh, J. P., et al. (2012). From acid to climate change. Science 338, 1153-1154. doi: $10.1126 /$ science. 1226514

Ryan, P. R., Tyerman, S. D., Sasaki, T., Furuichi, T., Yamamoto, Y., Zhang, W. H., et al. (2011). The identification of aluminum-resistance genes provides opportunities for enhancing crop production on acid soils. J. Exp. Bot. 62, 9-20. doi: $10.1093 /$ jxb/erq272

Sasaki, T., Ezaki, B., and Matsumoto, H. (2002). A gene encoding multidrug resistance (MDR)-like protein is induced by aluminum inhibitors of calcium flux in wheat. Plant Cell Physiol. 43, 177-185. doi: 10.1093/pcp/pcf025

Sharma, P., and Dubey, R. S. (2007). Involvement of oxidative stress and role of antioxidative defense system in growing rice seedlings eposed to toxic concentrations of aluminum. Plant Cell Rep. 26, 2027-2038. doi: 10.1007/s00299-007-0416-6

Sharma, P., Jha, A. B., Dubey, R. S., and Pessarakli, M. (2012). Reactive oxygen species, oxidative damage, and antioidative defense mechanism in plants under stressfull conditions. J. Bot. 2012:217037. doi: 10.1155/2012/217037

Silva, S., Pinto, G., Correia, B., Pinto-Carnide, O., and Santos, C. (2013). Rye oxidative stress under long term $\mathrm{Al}$ exposure. J. Plant Physiol. 170, 879-889. doi: 10.1016/j.jplph.2013.01.015

Šimonovičová, M., Tamás L., Huttová J., and Mistrík I. (2004). Effect of aluminium on oxidative stress related enzymes activities in barley roots. Biol. Plant. 48, 261-266. doi: 10.1023/B:BIOP.0000033454.95515.8a

Sinha, A. K., Giblen, T., AbdElgawad, H., De Rop, M., Asard, H., Blust, R., et al. (2013). Regulation of amino acid metabolism as a defensive strategy in the brain of three freshwater teleosts in response to high environmental ammonia exposure. Aquat. Toxicol. 130-131, 86-96. doi: 10.1016/j.aquatox.2013.01.003

Slesak, I., Libik, M., Karpinska, B., Karpinski, S., and Miszalski, Z. (2007). The role of hydrogen peroxide in regulation of plant metabolism and cellular signaling in response to environmental stresses. Acta Biochim. Pol. 54, 39-50.

Smirnoff, N. (1996). The function and metabolism of ascorbic acid in plants. Annu. Bot. 78, 661-669. doi: 10.1006/anbo.1996.0175

Stab, A., and Horst, W. (1995). "Effect of aluminum on membrane properties of soybean (Glycine max) cells in suspension cultures," in Plant Soil Interactions at Low pH, ed. R. A. Date (Dordrecht: Kluwer Academic Publishers), 279-284.

Tabaldi, L. A., Cargnelutti, D., Goncalves, J. F., Pereira, L. B., Castro, G. Y., Maldaner, J., et al. (2009). Oxidative stress is na early symptom triggered by aluminum in Al-sensitive potato plantlets. Chemosphere 76, 1402-1409. doi: 10.1016/j.chemosphere.2009.06.011

Tabuchi, A., and Matsumoto, H. (2001). Changes in cell-wall properties of wheat (Triticum aestivum) roots during aluminum-induced growth inhibition. Physiol. Plant. 112, 353-358. doi: 10.1034/j.1399-3054.2001.1120308.x

Van, H. L., Kuraishi, S., and Sakurai, N. (1994). Aluminum-induced rapid root inhibition and changes in cell-wall components of squash seedlings. Plant Physiol. 106, 971-976.

Voss, I., Sunil, B., Scheibe, R., and Raghavendra, A. S. (2013). Emerging concept for the role of photorespiration as an important part of abiotic stress response. Plant Biol. 15, 713-722. doi: 10.1111/j.1438-8677.2012.00710.x

Wang, Y. S., and Yang, Z. M. (2005). Nitric oxide reduces aluminum toxicity by preventing oxidative stress in roots of Cassia tora L. Plant Cell Physiol. 46, 1915-1923. doi: 10.1093/pcp/pci202

Willekens, H. (1997). Catalase is a sink for $\mathrm{H}_{2} \mathrm{O}_{2}$ and is indispensable for stress defense in $C_{3}$ plants. $E M B O$ J. 16, 4806-4816. doi: 10.1093/emboj/16.16.4806

Xu, F. J., Li, G., Jin, C. W., Liu, W. J., Zhang, S. S., Zhang, Y. S., et al. (2012). Aluminum-induced changes in reactive oxygen speies accumulation, lipid peroxidation and antioxidant capacity in wheat root tips. Biol. Plant. 56, 89-96. doi: 10.1007/s10535-012-0021-6

Yamamoto, Y., Kobayashi, Y., Devi, S. R., Rikiishi, S., and Matsumoto, H. (2002). Aluminum toxicity is associated with mitochondrial dysfunction and the production of reactive oxygen species in plant cells. Plant Physiol. 128, 63-72. doi: 10.1104/pp.010417 
Yamamoto, Y., Kobayashi, Y., Devi, S. R., Rikiishi, S., and Matsumoto, H. (2003). Oxidative stress triggered by aluminum in plant roots. Plant Soil. 255, 239-243. doi: 10.1023/A:1026127803156

Yang, J. L., Li, Y. Y., Zhang, Y. J., Zhang, S. S., Wu, Y. R., Wu, P., et al. (2008). Cell wall polysaccharides are specifically involved in the exclusion of aluminum from rice root apex. Plant Physiol. 146, 602-611. doi: 10.1104/pp.107.111989

Yin, L., Wang, S., Eltayeb, A. E., Uddin, M. I., Yamamoto, Y., Tsuji, W., et al. (2010). Overexpression of dehydroascorbate reductase, but not monodehydroascorbate reductase, confers tolerance to aluminum stress in transgenic tobacco. Planta 231, 609-621. doi: 10.1007/s00425-009-1075-3

Yokosho, K., Yamaji, N., and Ma, J. F. (2010). Isolation and characterization of two MATE genes in rye. Funct. Plant Biol. 37, 296-303. doi: 10.1099/ijs.0. 032292-0

Zhang, G., and Taylor, G. J. (1991). Effects of biological inhibitors on kinetics of aluminum uptake by excised roots and purified cell wall material of aluminumtolerant and aluminum-sensitive cultivars of Triticum aestivum L. J. Plant Physiol. 138, 533-539. doi: 10.1016/S0176-1617(11)80236-1
Zhu, H., Wang, H., Zhu, Y., Zou, J., Zhao, F. J., and Huang, C. F. (2015). Genomewide transcriptomic and phylogenetic analyses reveal distinct aluminumtolerance mechanisms in the aluminum-accumulating species buckwheat (Fagopyrum tataricum). BMC Plant Biol. 15:16. doi: 10.1186/s12870-01 4-0395-Z

Conflict of Interest Statement: The authors declare that the research was conducted in the absence of any commercial or financial relationships that could be construed as a potential conflict of interest.

Copyright (c) 2016 de Sousa, AbdElgawad, Han, Teixeira, Matos and Fidalgo. This is an open-access article distributed under the terms of the Creative Commons Attribution License (CC BY). The use, distribution or reproduction in other forums is permitted, provided the original author(s) or licensor are credited and that the original publication in this journal is cited, in accordance with accepted academic practice. No use, distribution or reproduction is permitted which does not comply with these terms. 